1 Suppression of DSB Formation by Pol $\beta$ in Active DNA 2 Demethylation is Required for Postnatal Hippocampal

\title{
3 Development
}

5 Akiko Uyeda, ${ }^{1}$ Kohei Onishi, ${ }^{1}$ Teruyoshi Hirayama, ${ }^{1,2}$ Satoko Hattori, ${ }^{3}$

6 Tsuyoshi Miyakawa, ${ }^{3}$ Takeshi Yagi, ${ }^{1,2}$ Nobuhiko Yamamoto $^{1}$ and

7 Noriyuki Sugo ${ }^{1, *}$

9 1. Graduate School of Frontier Biosciences, Osaka University, Suita, Osaka, 565-0871, 10 Japan.

11 2. AMED-CREST, Japan Agency for Medical Research and Development (AMED), 12 Suita, Osaka, 565-0871, Japan

13 3. Institute for Comprehensive Medical Science, Fujita Health University, Toyoake, Aichi, 470-1192, Japan.

Contact Info

*Correspodence: sugo@fbs.osaka-u.ac.jp

21 Number of pages: 51 pages

22 Number of figures and tables: 6 figures, 4 supplemental figures, 1 supplemental table

23 Number of words for whole manuscript: 38868 words /Abstract: words 147 


\section{Abstract}

2 Genome stability is essential for brain development and function. However, the

3 contribution of DNA repair to genome stability in neurons remains elusive. Here, we

4 demonstrate that the base excision repair protein Pol $\beta$ is involved in hippocampal

5 neuronal differentiation via a TET-mediated active DNA demethylation during early

6 postnatal stages. Pol $\beta$ deficiency induced extensive DNA double-strand breaks (DSBs) in

7 hippocampal neurons, and a lesser extent in cortical neurons, during a period in which

8 decreased levels of 5-methylcytosine were observed in genomic DNA. Inhibition of the

9 hydroxylation of 5-methylcytosine by microRNAs miR29a/b-1 expression diminished

10 DSB formation. Conversely, its induction by TET1 overexpression increased DSBs. The

11 damaged hippocampal neurons exhibited aberrant neuronal gene expression profiles and

12 dendrite formation. Behavioral analyses revealed impaired spatial learning and memory

13 in adulthood. Thus, Pol $\beta$ maintains genome stability in the active DNA demethylation

14 that occurs during postnatal neuronal development, thereby contributing to differentiation

15 and subsequent behavior.

\section{Keywords}

18 DNA repair, DNA demethylation, DNA double-strand break, hippocampal development, 19 learning and memory, neuronal differentiation. 


\section{Introduction}

2 Genome stability is crucial for both genetic and epigenetic regulation underlying gene

3 expression in the brain throughout life. DNA repair is essential to maintain genome 4 stability and has been well characterized through studies on cancer and immune cell 5 differentiation in mammals (Alt et al, 2013; Lindahl \& Wood, 1999). In the nervous 6 system, mouse models reveal that DNA repair dysfunction in neural progenitors 7 frequently leads to genome instability and neuronal apoptosis during the period of 8 neurogenesis (Deans et al, 2000; Gao et al, 1998; Gu et al, 2000; Lee et al, 2001; Lee et 9 al, 2009; Pulvers \& Huttner, 2009; Sugo et al, 2000). In addition, genetic diseases related to DNA repair defects include microcephaly, developmental disorders, and psychiatric 11 disorders (Madabhushi et al, 2014; McKinnon, 2013). Accumulation of somatic 12 mutations in neurons during development has been implicated in developmental brain 13 disorders such as autism and schizophrenia (McConnell et al, 2017; McKinnon, 2013; 14 Poduri et al, 2013). These studies suggest that DNA repair is likely to be critical for normal brain development and function. However, while DNA repair has been characterized in mitotic cells including neural progenitors, its role in neurons as postmitotic cells remains unclear. In brain development, postnatal neuronal differentiation is also a core process for circuit formation and activity-dependent refinement (Flavell \& Greenberg, 2008; Kolodkin \& Tessier-Lavigne, 2011). Thus, it is important to uncover novel aspects of DNA repair in neuronal differentiation and function. Base excision repair (BER) is mainly involved in the removal of DNA base damage and apurinic/apyrimidinic sites (Wilson et al, 2000). In addition, recent studies have revealed that BER also plays a role in the active DNA demethylation process as an epigenetic regulation (Schuermann et al, 2016; Wu \& Zhang, 2010). In this process, 5methylcytosine $(5 \mathrm{mC})$ is initially oxidized by TET enzymes and is converted to 5hydroxymethylcytosine (5hmC) (Ito et al, 2010; Ito et al, 2011; Tahiliani et al, 2009); the modified base is finally recognized by thymine DNA glycosylase and replaced with 
1 Cortázar et al, 2011, He et al, 2011, Weber et al, 2016). DNA methylation and

2 demethylation often play a central role in cell differentiation (Moore et al, 2013; Wu \&

3 Zhang, 2017). In the neuronal epigenome, dynamic changes in the DNA methylation level

4 are observed during brain development (Lister, 2013; Sharma, 2016; Simmons et al,

5 2013) and affect neuronal gene expression, which is implicated in neurogenesis,

6 maturation, and plasticity (Feng et al, 2010; Moretti, et al, 2006; Sanosaka et al, 2017).

7 This regulation also contributes to learning and memory (Gontier et al, 2018; Kaas et al,

8 2013; Li et al, 2014; Rudenko et al, 2013).

Studies using conventional Pol $\beta$-deficient mice show increased neuronal apoptosis during the period of neurogenesis in the developing nervous system rather than in other tissues, and the mice die just after birth (Sugo et al, 2000). The p53-dependent pathway regulates neuronal apoptosis after the final mitosis (Sugo et al, 2007; Sugo et al, 2004). Our previous study focusing on spatiotemporal roles using forebrain-specific conditional knockout Emxl-Cre/Pol $\beta^{f l / f l}$ and Nex-Cre/Pol $\beta^{f l f l}$ mice indicates that Pol $\beta$ deficiency in neural progenitors rather than in postmitotic neurons specifically leads to an increase of DNA double-strand breaks (DSBs) associated with replication in the embryonic cortex (Onishi et al, 2017). The accumulation of DSBs frequently induces neuronal apoptosis and abnormal axon projection. Furthermore, impairment of the DNA demethylation process is a potential cause of DSBs in Pol $\beta$-deficient progenitors, suggesting that epigenetic regulation via BER including Pol $\beta$ in neural progenitors is essential for neuronal survival and differentiation. However, how Pol $\beta$ contributes to subsequent neuronal development, gene expression, and further cognitive function is not fully understood.

To address this issue, we investigated the role of Pol $\beta$ using Nex-Cre/Polfflffl mice, in which postmitotic excitatory neurons lack Pol $\beta$ expression. We found that the mutant mice exhibited extensive DSB formation, but not apoptosis, in hippocampal neurons more so than in cortical neurons during early postnatal stages, in which the levels of $5 \mathrm{mC}$ and $5 \mathrm{hmC}$ in the genome decreased. In vivo manipulation of active DNA 
1 demethylation during this period altered the extent of DSBs in Pol $\beta$-deficient neurons.

2 Furthermore, Pol $\beta$ deficiency affected gene expression profiles and dendritic morphology

3 of developing hippocampal neurons, and impaired hippocampus-related learning and

4 memory. These findings suggest that genome stability mediated by Pol $\beta$ is required for

5 active DNA demethylation leading to normal postnatal neuronal development and 6 memory function.

7

8 


\section{$1 \quad$ Results}

2 Polß-deficient neurons show accumulation of DNA double-strand breaks in 3 postnatal development

4 To investigate the spatiotemporal role of Pol $\beta$ in postmitotic neuronal development, we 5 used Nex-Cre/Pol $\beta^{f l / f l}$ mice (Onishi et al, 2017). In control Pol $\beta^{f l f l}$ mice, Pol $\beta$ 6 immunoreactivity was roughly ubiquitous throughout the neocortex and the hippocampus 7 at P2, and its subcellular localization was predominantly nuclear (Supplemental Figure 8 (Figure S) 1A, B). As expected, excitatory neurons including Ctip2-positive cells lost 9 Pol $\beta$ expression in the neocortex and the hippocampus of $N e x-C r e / P o l \beta^{f l f l}$ mice (Figure $10 \mathrm{~S} 1 \mathrm{~A}, \mathrm{~B})$. However, the cortical laminar organization and hippocampal cytoarchitecture in 11 Nex-Cre/Pol $\beta^{f l f l}$ mice seemed to be similar to those in control Pol $\beta^{f l / f l}$ mice (Figure S1A$12 \mathrm{C})$.

To examine whether Pol $\beta$ deficiency affects genome stability in neuronal 14 development, DSB formation was investigated at embryonic (E16.5 and 18.5) and 15 postnatal stages (P2, 15, 28 and 90$)$ by immunohistochemical analysis with an antibody against $\gamma \mathrm{H} 2 \mathrm{AX}$, a DSB marker (Onishi et al, 2017, Rogakou et al, 1999, Rogakou et al, 1998). Strong signals of $\gamma \mathrm{H} 2 \mathrm{AX}$ foci were frequently found in Nex-Cre/Pol $\beta^{f l f l}$ hippocampal pyramidal cell nuclei at $\mathrm{P} 15$, while only a few cells were focus-positive in controls (Figure 1A, B). Quantitative analyses showed that both the number of foci in a nucleus and the fraction of focus-positive cells were significantly larger in NexCre/Pol $\beta^{f l f l}$ pyramidal cells than in control Pol $\beta^{f l f l}$ (Figure 1D, E). Consistent with these observations, immunostaining with 53BP1, a protein involved in non-homologous end joining (NHEJ), also showed focus formation in Nex-Cre/Polfflfll mice (Figure S1D), strongly indicating that the foci were due to DSB formation (Schultz et al, 2000). The developmental time course further demonstrated that $\gamma \mathrm{H} 2 \mathrm{AX}$ foci were undetectable

26 during the embryonic stages (Figure S2A) and appeared from P2 (Figure 2A). The signals

27 just peaked at P15 and then decreased until the 3-month adult stage (Figure 2A, C, D). 
1 Similarly, a fraction of neocortical neurons in Nex-Cre/Pol $\beta^{f l f l}$ mice also exhibited a

2 transient increase of $\gamma \mathrm{H} 2 \mathrm{AX}$ focus formation with a comparable developmental time

3 course (Figure 1A, C-E and 2B, E, F), although the increase was less marked than in

4 hippocampal pyramidal neurons (Figure 1D, E; the fraction of $\gamma \mathrm{H} 2 \mathrm{AX}$ focus-positive 5 cells at P15 was $79 \%$ in the hippocampus and $20 \%$ in the neocortex). These results

6 indicate that Pol $\beta$ deficiency transiently increases DSB formation during postnatal 7 neuronal development, although the extent of DSBs differs between brain regions.

A next question is whether DSB accumulation induces neuronal apoptosis as 9 observed in Emxl-Cre/Pol/ $\beta^{\text {flfl }}$ mice (Onishi et al, 2017). Anti-cleaved caspase-3 10 immunohistochemistry was performed in Nex-Cre/Pol $\beta^{f l / f l}$ mice. Unexpectedly, few 11 cleaved caspase 3-positive cells were observed in Nex-Cre/Pol $\beta^{f l / f l}$ hippocampus and 12 cortex at P2 and P15, during which DSB formation increases. The abundance of apoptotic 13 cells was similar to that in control Pol $\beta^{f l f l}$ mice (Figure S2C). Taken together, these results suggest that Pol $\beta$ deficiency leads to genome instability, but does not affect cell survival,

15 in hippocampal and cortical neurons during postnatal development.

\section{Pol $\beta$ is required for base excision repair in postmitotic neurons}

18 Polß is a key enzyme in BER but not in DSB repair (DSBR) (Sobol et al, 1996, Wilson et al, 2000). The DSB formation in Pol $\beta$-deficient neurons may be due to accumulation of single-strand breaks (SSBs) as BER intermediates (Caldecott, 2003). To test this possibility, immunohistochemical analysis with an antibody against XRCC1, an SSB marker (Caldecott, 2003, El-Khamisy et al, 2003), was performed. Fluorescence intensity of XRCC1 was significantly increased in P15 Nex-Cre/Pol/fl/fl hippocampal CA1 pyramidal cell nuclei compared to control Pol $\beta^{f l f l}$ nuclei (Figure 3A-C). In addition, the XRCC1 intensity increased even during normal hippocampal development from P2 to P15 (Figure 3A, C), similar to developmental changes of the $\gamma \mathrm{H} 2 \mathrm{AX}$ foci in Nex- 
1 of SSBs in Nex-Cre/Pol $\beta^{f l f l}$ mice leads to DSB formation. examined to reveal the role of Pol $\beta$ in BER and DSBR. Primary cultured neurons from

4 E16.5 control or Nex-Cre/Pol $\beta^{f l f l}$ mouse cortex were treated with 5 methylmethanesulfonate (MMS), which induces base damage (Beranek, 1990; Kulkarni 6 et al, 2008; Sobol et al, 1996), or etoposide, an inhibitor of topoisomerase II that induces 7 DSBs (Dobbin et al, 2013; Ross et al, 1984). Pol $\beta$-deficient neurons showed higher sensitivity to MMS than control (Figure 3D, E). In contrast, there was no significant

9 difference following the etoposide treatment (Figure 3D, E). In addition, $\gamma \mathrm{H} 2 \mathrm{AX}$ focus

10 formation after MMS treatment was significantly increased in neuronal cultures from 11 Nex-Cre/Pol $\beta^{f l f l}$ mice compared to those from Pol $\beta^{f l f l}$ mice (Figure 3F-H). Taken together, 12 these results demonstrate that Pol $\beta$ is required for BER rather than DSBR, suggesting that 13 highly accumulated SSBs are converted to DSBs in Pol $\beta$-deficient neurons during 14 postnatal development.

\section{Loss of Pol $\beta$ in active DNA demethylation causes DSBs in developing neurons}

17 To examine the possibility that active DNA demethylation was a cause of the DSB

18 formation in Pol $\beta$-deficient neurons during postnatal development (Lister et al, 2013;

19 Sharma et al, 2016; Wu \& Zhang, 2017), developmental changes in 5mC and 5hmC levels

20 were quantified between P2 and P28. Immunoblot analysis with specific antibodies

21 revealed that both $5 \mathrm{mC}$ and $5 \mathrm{hmC}$ levels decreased strongly in control Pol/ $\beta^{f l / f l}$ hippocampus between P2 and P15 (Figure 4A, B), during which the extent of SSB and DSB formation increased (Figure 2, 3A-C). This suggests that many DNA demethylation reactions occur on the genome during this period.

We examined whether inhibition of the active DNA demethylation process could affect DSB formation in Pol $\beta$-deficient hippocampal neurons in vivo. Overexpression of microRNAs miR29a and miR29b-1 has been reported to inhibit expression of several 
1 genes involved in DNA methylation and demethylation processes, resulting in a decrease

2 in 5hmC level in transfected cells (Cheng et al, 2013; Hysolli et al, 2016). The miRNA expression vector was transfected into CA1 neurons in Nex-Cre/Pol ${ }^{f l f l}$ hippocampus using an in utero electroporation technique. $\operatorname{miR} 29 \mathrm{a} / \mathrm{b}-1$ efficiently decreased the $5 \mathrm{hmC}$ level in the transfected hippocampal neurons (Figure 4C). The numbers of $\gamma \mathrm{H} 2 \mathrm{AX}$ foci and of focus-positive cells in $\gamma \mathrm{H} 2 \mathrm{AX}$ foci were significantly lower in the transfected neurons than in the surrounding untransfected neurons of P15 Nex-Cre/Polf $\beta^{f l f l}$ hippocampus (Figure 4D-G), indicating that inhibition of active DNA demethylation suppresses DSB formation.

Conversely, we tested whether induction of active demethylation promotes DSB formation in Pol $\beta$-deficient cortical neurons. TET1 catalytic domain (TET1CD), which induces $5 \mathrm{hmC}$ more efficiently than full-length TET1 (Tahiliani et al, 2009), was overexpressed in cortical neurons using in utero electroporation. As expected, the $5 \mathrm{hmC}$ level increased in both the transfected Pol $\beta^{f l f l}$ and Nex-Cre/Polfflfll cortical neurons at P7 (Figure $4 \mathrm{H}$ ). The $\gamma \mathrm{H} 2 \mathrm{AX}$ foci were increased in the transfected neurons compared to the untransfected neurons of Nex-Cre/Pol $\beta^{f l f l}$ cortex, but not of Pol $\beta^{f l f l}$ cortex (Figure 4I). Quantitative analysis also demonstrated that both parameters of $\gamma \mathrm{H} 2 \mathrm{AX}$ foci were significantly increased in the transfected neurons relative to the surrounding neurons in Nex-Cre/Pol $\beta^{f l / f l}$ cortex, indicating that induction of active DNA demethylation is sufficient to promote DSB formation in Pol $\beta$-deficient cortical neurons (Figure 4J, K). Finally, to modulate the endogenous active DNA demethylation process, cultured cortical neurons from E16.5 Nex-Cre/Pol $\beta^{f l f l}$ and Pol $\beta^{f l f l}$ mice were treated with vitamin C, which induces TET1 activity (Blaschke et al, 2013). Immunocytochemistry with anti-5hmC antibody showed an apparent increase in 5hmC level following 24-h vitamin $\mathrm{C}$ treatment in both control and Polß-deficient neuronal nuclei (Figure S3A).

26 Analysis of the DSB formation under this culture condition demonstrated that both the number of $\gamma \mathrm{H} 2 \mathrm{AX}$ foci and the proportion of focus-positive cells were significantly increased in $\mathrm{Nex}$-Cre/Pol $\beta^{f l f l}$ neurons but not in controls (Figure S3B-D). Together, these 
1 results suggest that active DNA demethylation is a primary cause of DSB formation in

2 Pol $\beta$-deficient neurons during postnatal development.

4 Polß deficiency affects gene expression and dendrite morphology of hippocampal neurons during postnatal development

6 To investigate the possibility that active DNA demethylation defects and/or DSB

7 formation alter gene expression in Pol $\beta$-deficient neurons, RNA-seq analysis was 8 performed with RNA extracted from P15 control Pol/ $\beta^{f l f l}$ and Nex-Cre/Pol $\beta^{f l f l}$

9 hippocampus. Overall, 219 genes were found to be downregulated, and 199 upregulated, 10 in the Nex-Cre/Polfflflf hippocampus compared to the control (Figure 5A; $\mathrm{n}=3, \mathrm{p}<0.05$, 11 fold change $>1.2$ ). A functional annotation analysis of these 418 differentially expressed 12 genes (DEGs) was performed using Ingenuity Pathway Analysis (IPA) software (Figure 13 S4A-C). Genes related to nervous system development and function $\left(p=1.41 \times 10^{-2}\right)$ and 14 to neurological diseases $\left(\mathrm{p}=1.26 \times 10^{-4}\right)$, in addition to cancer, were significantly 15 enriched in the DEGs (Figure 5B, C). In the canonical pathways identified by the IPA, 16 signaling pathways related to cell cycle regulation, DNA damage response, and cancer 17 cells were primarily suggested (Figure 5D), which may reflect a response to DSB 18 formation in Pol $\beta$-deficient neurons. In addition, among the top hits, the assembly of RNA 19 polymerase I complex $(p=0.012)$, the opioid signaling pathway $(p=0.013)$, and the

$20 \mathrm{Wnt} / \mathrm{Ca}+$ pathway $(\mathrm{p}=0.016)$, which are known to relate to neuronal development and 21 learning and memory in the hippocampus, were included (Capitano et al, 2016; Inestrosa \& Varela-Nallar, 2015; Williams et al, 2001). These results indicate that Pol $\beta$ deficiency affects the regulation of genes involved in neuronal development and function.

24 Furthermore, a marked similarity was identified in the gene expression profiles between the Polß-deficient hippocampus and TET3 shRNA-transfected hippocampal neurons (Yu et al, 2015) using Illumina correlation engine software (Figure S4D), suggesting that some of the overlapped genes are under the control of active DNA demethylation. 
The altered gene expression in the Nex-Cre/Pol $\beta^{f l f l}$ hippocampus may affect

2 development of hippocampal neurons. Dendritic morphology of CA1 pyramidal neurons

3 was examined in the Nex-Cre/Pol $\beta^{f l / f l}$ and $P o l \beta^{f l / f l}$ hippocampus. To visualize the 4 morphology of individual neurons, sparse cell labeling was performed with the

5 Supernova system using in utero electroporation (Luo et al, 2016; Mizuno et al, 2014).

6 While both apical and basal dendrites of Nex-Cre/Pol $\beta^{f l / f l}$ CA1 neurons appeared to be 7 similar to those in the control (Figure 5E), dendritic width (Pol/ $\beta^{f l f l}$ vs Nex-Cre/Pol $\beta^{\mathrm{fl} / \mathrm{fl} \text {; }}$ $8301 \pm 28 \mu \mathrm{m}, 228 \pm 13 \mu \mathrm{m}, \mathrm{p}=0.0204$, ANOVA) and total dendrite length $\left(\right.$ Pol $^{f f l f l} \mathrm{vs}$ $9 \quad$ Nex-Cre/Pol $\beta^{\mathrm{fl} / \mathrm{fl} ;} 4775 \pm 263 \mu \mathrm{m}, 3997 \pm 207 \mu \mathrm{m}, \mathrm{p}=0.0248$, ANOVA) were 10 significantly lower in Nex-Cre/Pol $\beta^{f l f l}$ than in Pol $\beta^{f l / f l}$ neurons (Figure 5F). These results 11 suggest that Pol $\beta$ is required for dendrite formation in the developing hippocampus.

13 Nex-Cre/Polf flffl mice show impaired spatial reference memory and contextual fear 14 memory

15 To further examine the involvement of Pol $\beta$ in neuronal functions, Nex-Cre/Pol $\beta^{f l / f l}$ mice and their littermates were subjected to a comprehensive behavioral test battery (Shoji et al, 2018). Significant behavioral differences between control and mutant mice were found in several behavioral tests (Supplemental Table (Table S) 1). Notably, in the Barnes maze test, which is widely used for assessing spatial learning and memory, the number of errors to reach the target was significantly larger in Nex-Cre/Pol $\beta^{f l f l}$ mice than in control Pol $\beta^{f l f l}$ mice (Figure 6A; $p=0.0003$ ). Consistent with this, the traveling distance and the latency were also significantly different between the two groups (Figure 6B, C). In the probe test at one day after final trial of the acquisition test, Nex-Cre/Pol $\beta^{f l / f l}$ mice spent significantly less time around their targets compared to the control (Figure 6D, 34.6 $\pm 3.9 \%, 20.7 \pm$ $2.1 \%, \mathrm{p}=0.0031$ ), confirming impaired spatial learning and memory due to distal environmental cues. This behavior was observed at one month after the acquisition test (Table S1). In the contextual and cued fear conditioning test, which is used to assess fear 
1 memory, no difference was found in freezing time during the conditioning phase and at

2 one day after the conditioning (Figure 6E, Table S1). However, Nex-Cre/Pol $\beta^{f l f l}$ mice

3 showed a shorter freezing time in the contextual test at one month after the conditioning,

4 but not in the cued test (Figure 6F, G). In addition, Nex-Cre/Pol $\beta^{f l / f l}$ mice also showed

5 reduced anxiety behavior in the elevated plus maze (Figure 6H, I). Taking into

6 consideration that spatial memory, contextual fear memory, and anxiety behavior are

7 dependent on hippocampus function (Jimenez et al, 2018; Kim \& Fanselow, 1992;

8 Koopmans et al, 2003), these results suggest that the lack of Pol $\beta$ tends to impair

9 hippocampus-dependent functions.

10 


\section{Discussion}

2 The present study demonstrated that the loss of Pol $\beta$ leads to DSB accumulation in

3 developing hippocampal neurons, and to a lesser extent in cortical neurons, which is

4 attributable to a failure of active DNA demethylation. The DSB accumulation in Pol $\beta$ -

5 deficient neurons did not induce apoptosis, but affected gene expression and dendritic

6 morphology in hippocampal neurons. Furthermore, behavioral tests demonstrated that the

7 loss of Pol $\beta$ impaired hippocampal-dependent function. These results suggest that

8 genome maintenance by Pol $\beta$ contributes to hippocampal neuronal differentiation and

9 functional circuit formation via epigenetic regulation of gene expression (Figure 6J).

11 Polß-dependent BER is involved in active DNA demethylation during postnatal

12 development of the nervous system

13 Our results show that Pol $\beta$ plays a role in an active DNA demethylation process in 14 postmitotic neuronal development (Figure 4), giving a first insight into its function in 15 epigenome regulation in vivo (Weber et al, 2016). In the case of DNA demethylation in 16 postmitotic cells, the TET-dependent active process involving BER seems to be a major 17 reaction because the passive process coupled with DNA replication is dysfunctional 18 (Schuermann et al, 2016; Wu \& Zhang, 2017). Indeed, the decrease in DNA methylation level was paralleled by accumulation of SSBs, which may be BER intermediates, in the developing hippocampal genome (Figure 3A, B, 4A, and B). The timing between $\mathrm{P} 2$ and P15 is roughly consistent with previous studies (Lister et al, 2013; Simmons et al, 2013). Data in the culture experiment (Figure S3A) suggest that vitamin $\mathrm{C}$ is also important to promote active DNA demethylation during this period (Blaschke et al, 2013).

Moreover, Pol $\beta$ deficiency altered expression of neuronal genes that are involved in transcription regulation (Olig2, Hdac9), the cytoskeleton (Flna, Homer2), and synaptic transmission (Drd2, Chrna5) (Figure 5A-C). The altered gene expression patterns were observed consistently in all tested samples of hippocampus in $\mathrm{Nex}-\mathrm{Cre} / \mathrm{Pol} \mathrm{f}^{f l f l}$ mice, 
1 meaning that the alterations are determinate rather than stochastic, as is different from

2 spontaneous DNA base damage (Figure 5A-C). Expression profiles of TET3 shRNA

3 knockdown hippocampal neurons are also similar to those of Nex-Cre/Pol/ $\beta^{f l f l}$

4 hippocampus (Figure S4D) (Rudenko et al, 2013, Yu et al, 2015). These results support

5 the notion that Pol $\beta$ contributes to specific gene regulation via active DNA demethylation

6 during hippocampal development. The greater abundance of DSBs in hippocampal than

7 in cortical neurons may reflect distinct gene expression profiles during this period (Figure

8 1). Therefore, it is likely that Pol $\beta$-dependent active DNA demethylation is involved in

9 epigenetic regulation of nervous system development, although we need more studies

10 focusing on neuronal cell types, developmental stages, and neural activities (Gontier et

11 al, 2018; Kaas et al, 2013; Li et al, 2014; Yu et al, 2015; Zhu et al, 2016).

13 Genome instability arising from Polß deficiency leads to long-lasting effects on the 14 genome and epigenome, rather than to apoptosis

15 We found that Pol $\beta$ is required for the genome stability of postmitotic neurons (Figure 1).

16 Combining this observation with previous studies, Pol $\beta$-dependent BER appears to play

17 a key role in suppressing DSB formation at two distinct developmental stages, namely

18 neurogenesis and postnatal neuronal differentiation. Why does the loss of Pol $\beta$ induce

19 DSBs in developing neurons? Pol $\beta$ deficiency generally increases nicks and/or gaps as

20 SSBs in the genome (Sobol et al, 1996). Indeed, SSBs increased significantly in Pol $\beta$ -

21 deficient neurons in vivo (Figure 3A-C). Although DNA replication can promote DSB

22 formation from a single SSB in the case of mitotic neural progenitors (Kuzminov, 2001;

23 Onishi et al, 2017), accumulation of SSBs may directly induce DSBs in postmitotic

24 neurons. Supporting this notion, base damage introduced by MMS treatment induced

25 DSBs in Polß-deficient neuronal cultures (Figure 3F-H). On the other hand, neuronal

26 apoptosis was undetectable in $\mathrm{Nex}$-Cre/Pol $\beta^{f l f l}$ hippocampal neurons (Figure S2C).

27 Induction of apoptosis seems to be dependent on not only the extent of DSBs but also p53 
1 pathway activity (Chong et al, 2000; Sugo et al, 2004).

3 DSB formation in postmitotic neurons (Figure 1). However, the extent of $\gamma \mathrm{H} 2 \mathrm{AX}$ foci in

$4 \quad$ Nex-Cre/Pol $f^{f l f l}$ mice declined after a peak at P15 (Figure 2). This suggests that DSBs in

5 Pol $\beta$-deficient neurons are repaired by the DSBR pathway. Considering that postmitotic

6 neurons only have NHEJ activity, which is error-prone DNA repair compared to

7 homologous recombination in mitotic cells, mutations such as insertions/deletions are

8 likely introduced into the DSB sites (Lieber, 2010). It will be interesting to determine

9 whether DSBs and/or DSB-induced de novo somatic mutations are intensively introduced

10 into mC-rich enhancer and promoter regions in neuronal genes. Indeed, the human

11 neuronal genome and epigenome are drastically altered in the developing brain and this

12 probably has a long-lasting influence on the brain into adulthood. (Cai et al, 2014; Lodato

13 et al, 2015; Rehen et al, 2005; Stroud et al, 2017; Wei et al, 2016). Recent work has

14 revealed that such alterations is increased in psychiatric diseases, although the underlying

15 mechanism remains uncertain (Bundo et al, 2014; Fromer et al, 2014; Iossifov et al, 2014;

16 McConnell et al, 2013). Our findings indicate that active DNA demethylation-associated

17 DNA damage is a potential cause of de novo somatic mutations and an aberrant

18 epigenome in brain developmental disorders.

\section{The role of Pol $\beta$ in structure and function of the cerebral cortex}

21 Pol $\beta$ plays a role in the molecular bases underlying dendrite formation (Figure 5E, F). To date, TET1 and TET3 have also been shown to be involved in synaptic excitability and plasticity (Rudenko et al, 2013, Yu et al, 2015). These data suggest that DNA demethylation is necessary for neuronal development. On the other hand, it has also been demonstrated that the DNA methyltransferases Dnmt1, Dnmt3a, Dnmt3b, and the methyl-

$26 \mathrm{CpG}$ binding protein $\mathrm{MeCP} 2$ are involved in dendritic arborization (Cohen et al, 2011;

27 Feng et al, 2010; Golshani et al, 2005; Moretti et al, 2006; Zhou et al, 2006). Therefore, 
1 gene expression mediated by the bidirectional regulation of DNA methylation and

2 demethylation may be crucial for neuronal development and circuit formation.

A comprehensive behavioral test with $N e x-C r e / P o l \beta^{f l / f l}$ mice showed a

4 remarkable impairment in spatial reference memory and contextual fear memory (Figure

5 6A-G). This concurs with recent reports suggesting that active DNA demethylation is

6 involved in learning and memory in adult mice (Gontier et al, 2018; Kaas et al, 2013; Li

7 et al, 2014; Rudenko et al, 2013). However, considering that DSB accumulation in Pol $\beta$ -

8 deficient neurons is most prominent in early postnatal stages, we propose that DSBs

9 and/or DSB-induced de novo mutations arising from the impairment of active DNA

10 demethylation alter gene expression leading to circuit formation, and have a long-lasting

11 influence on learning and memory. Indeed, the functional impairment was striking in the

12 hippocampus (Figure 6, Table S1), in which DSBs accumulated extensively during the

13 early postnatal stages (Figure 1, 2).

14 While active DNA demethylation is revealed as a potential source of DNA 15 damage during early postnatal stages in Nex-Cre/Pol $\beta^{f l f l}$ mice, we cannot completely rule 16 out the possibility that oxidative stress causes DNA damage, leading to cognitive 17 dysfunction in the adult (Wilson \& McNeill, 2007). Indeed, Polß-dependent impairment 18 of cognitive function is reportedly accelerated in aged brains and Alzheimer's disease 19 models (Sykora et al, 2015). Moreover, the expression of DNA repair enzymes including 20 Polß gradually decreases with increased oxidative DNA damage associated with aging 21 (Lu et al, 2004; Nowak et al, 1990; Rao et al, 2001; Wilson \& McNeill, 2007). Therefore, 22 although pathological changes with aging can affects the role of Pol $\beta$ in neurons, our 23 findings provide a key insight into its role during early postnatal development, which has 24 long-lasting cognitive and behavioral outcomes. 


\section{Methods}

\section{Animals}

3 All experiments were conducted under the guidelines for laboratory animals of the

4 Graduate School of Frontier Biosciences, Osaka University. The protocol was approved

5 by the Animal Care and Use Committee of the Graduate School of Frontier Biosciences,

6 Osaka University and Fujita Health University. $\mathrm{Nex}^{\mathrm{Cre} /+} \mathrm{Pol} / \beta^{f l f l}\left(\mathrm{Nex}-\mathrm{Cre} / \mathrm{Pol} / \beta^{f l f l}\right)$ mice

7 were generated as described previously (Goebbels et al, 2006; Gu et al, 1994; Iwasato et

8 al, 2000; Onishi et al, 2017). Both male and female mice were used in all experiments

9 expect RNA-seq analysis and the behavioral test. Noon of the day on which the vaginal

10 plug was detected was designated as embryonic day 0.5 (E0.5) and the day of birth was

11 designated as postnatal day 0 ( $\mathrm{P} 0)$. Genotyping was performed using the following

12 primers: Pol $\beta$ locus: 5'-CCACACCGAAGTCCTCTGAT-3', 5'-

13 AGGCTGGCCTCAGACTCATA-3' and 5'-CTGGCTCACGTTCTTCTC-3'; Cre locus:

14 5'-GCAGAACCTGAAGATGTTCGCGAT-3' 5'

15 AgGTATCTCTGACCAGAGTCATCC-3'.

\section{Cell cultures}

18 Pregnant mice were deeply anesthetized with pentobarbital (50 mg/kg, i.p.). Cortices were dissected from E16.5 embryos in ice-cold HBSS and then minced with fine scissors in PBS. The minced tissues were incubated with $0.125 \%$ trypsin and $0.02 \%$ EDTA in PBS

21 for $5 \mathrm{~min}$ at $37^{\circ} \mathrm{C}$, and then triturated thoroughly using a fire-polished Pasteur pipette.

22 After centrifugation, the cells were resuspended in DMEM/F12 medium (Life

23 Technologies) supplemented with B27 (Life Technologies) and 5\% fetal bovine serum

24 (Hyclone). A suspension containing $2.0 \times 10^{5}$ cells was plated with culture medium on a $2512 \mathrm{~mm}$ micro coverglass (Matsunami) in a multi-well dish (Thermo Scientific) coated 26 with $0.1 \mathrm{mg} / \mathrm{ml}$ poly-L-ornithine (Sigma, P3655). The cultures were maintained at $37^{\circ} \mathrm{C}$ 27 in an environment of 5\% $\mathrm{CO}_{2}$ and humidified $95 \%$ air. 


\section{$1 \quad$ Plasmids}

2 pFN21AE2295, containing HaloTag-human TET1 cDNA, was purchased from Promega.

3 To generate TET1 catalytic domain (TET1CD) expression vector pCAGGS-TET1CD,

4 TET1CD was amplified from pFN21AE2295 by PCR with the following primers:

5 TET1CD-F (+start) 5'-ATGGAACTGCCCACCTGCAGCTGTCT-3' and TET1CD-R

6 (+stop) 5'-TCAGACCCAATGGTTATAGGGCCCCG-3'. The PCR product was

7 subcloned into pGEM-T Easy vector (A1360, Promega). An EcoRI-digested fragment

8 containing TET1CD was then ligated to EcoRI-digested pCAGGS vector (Niwa et al,

9 1991). To generate pCAGGS-miR29a/b-1, the miR29a/b-1 cluster locus was amplified

10 from mouse genomic DNA by PCR with the following primers: miR29a/b-1 F: 5'-

11 TGtGTtGCTTtGCCTTtGaGAGGA-3' and miR29a/b-1 R: 5'-

12 CACATAGGGATAGTCACCTAGCCTG-3'; the product was subcloned into pGEM-T

13 Easy vector. An EcoRI-digested fragment containing miR29a/b-1 locus was then ligated

14 to EcoRI-digested pCAGGS vector. Supernova vectors pTRE-Flpe-WPRE (pK036) and

15 pCAG-FRT-stop-FRT-tRFP-ires-tTA-WPRE (pK037) were kindly gifted from Dr.

16 Iwasato (Luo et al, 2016). These vectors were cotransfected with pCAGGS-EGFP. All

17 plasmids were purified with the PureLink HiPure Plasmid Maxiprep Kit (Invitrogen), and

18 then dissolved in PBS.

In utero electroporation

21 In utero electroporation was performed on E15.5 pregnant mice as previously described

22 (Fukuchi-Shimogori \& Grove, 2001, Tabata \& Nakajima, 2001, Tomita, Kubo et al, 2011).

23 Pregnant mice were deeply anesthetized with isoflurane (Wako Chemicals) using 24 inhalation anesthesia equipment (KN-1071-1, Natsume). Plasmids (1-3 $\mu \mathrm{g})$ were injected 25 to the lateral ventricle with a glass micropipette connected to an injector (IM-30, 26 Narishige). Electric pulses were delivered with disc-type electrodes (LF650P3 or 27 LF650P5, BEX) connected to an electroporator (CUY21, BEX). Five 35-V pulses of 50 
1 ms duration were applied at intervals of $950 \mathrm{~ms}$.

\section{Pharmacological treatment}

4 For a cell survival assay, cells at 3-4 DIV were incubated with culture medium containg 5 0-0.8 mM methylmethanesulfonate (MMS, Sigma, 129925) or 0-8 $\mu \mathrm{M}$ etoposide (Sigma, 6 E1383) for $1 \mathrm{~h}$, washed once with DMEM/F12 medium, and allowed to recover in 7 conditioned medium for $24 \mathrm{~h}$. To induce DNA base damage, cells at 14 DIV were treated 8 with culture medium containing $0.4 \mathrm{mM}$ MMS for $1 \mathrm{~h}$, and then fixed. To induce Tet9 dependent DNA demethylation, cells at 14 DIV were treated with culture medium containing $100 \mu \mathrm{g} / \mathrm{ml} \mathrm{L-ascorbic} \mathrm{acid} \mathrm{2-phosphate} \mathrm{(vitamin} \mathrm{C,} \mathrm{Sigma,} \mathrm{49752)} \mathrm{for} 24 \mathrm{~h}$,

11 and then fixed.

Immunostaining

14 Mice were deeply anesthetized and perfused with phosphate buffered saline (PBS, pH 15 7.4) followed by $2 \%$ paraformaldehyde (PFA) in $0.1 \mathrm{M}$ phosphate buffer ( $\mathrm{PB}, \mathrm{pH} 7.4)$.

16 Their brains were postfixed in the same fixative on ice for $2 \mathrm{~h}$, equilibrated with $25 \%$ 17 sucrose in PBS, frozen in OCT compound (Sakura Finetech), and then sectioned at 10 or $1820 \mu \mathrm{m}$ using a cryostat (CM1850, Leica). The sections were permeabilized and blocked 19 for $1 \mathrm{~h}$ at room temperature in buffer $\mathrm{G}(0.1$ or $1.0 \%$ Triton X-100, 5\% normal goat serum 20 (Vector Laboratories) in PBS). They were then incubated at $4{ }^{\circ} \mathrm{C}$ overnight with the 21 following primary antibodies diluted in buffer G: rabbit polyclonal anti-cleaved caspase223 (Asp175) (Cell Signaling, \#9661) at 1:250, rabbit polyclonal anti-histone H2AX 23 phosphor Ser139 (Active Motif, AR-0149-10) at 1:200, rabbit polyclonal anti-53BP1 24 (Gene Tex, GTX102595) at 1:200, rabbit monoclonal anti-XRCC1 (Abcam, ab134056) 25 at 1:200, rat polyclonal anti-Ctip2 (Abcam, ab18465) at 1:800, rat monoclonal anti-GFP 26 (Nacalai Tesque, GF090R) at 1:1000, and rabbit polyclonal anti 527 hydroxymethylcytosine (5hmC) (Active Motif, 39769) at 1:20000. Immunostaining of 
1 Pol $\beta$ was performed as described previously (Onishi et al, 2017). For XRCC1 and 5hmC

2 immunostaining, the sections were treated with $10 \mathrm{mM}$ sodium citrate buffer ( $\mathrm{pH}$ 6.0) for

$310 \mathrm{~min}$ at $98^{\circ} \mathrm{C}$ using an autoclave. For co-immunostaining with anti-5hmC and -GFP

4 antibodies, anti-GFP antibody was preincubated overnight at $4{ }^{\circ} \mathrm{C}$ before the antigen

5 retrieval step. Primary antibodies were detected by incubation with the secondary

6 antibodies Alexa488-conjugated anti-rabbit IgG (A-11034, Invitrogen), Alexa488-

7 conjugated anti-rat IgG (A-11006, Invitrogen), Alexa594-conjugated anti-rabbit IgG

8 (A21207, Invitrogen), Cy3-conjugated anti-mouse IgG (AP192C, Millipore), Cy3-

9 conjugated anti-rabbit $\operatorname{IgG}$ (AP182C, Millipore), and Cy3-conjugated anti-rat IgG

10 (AP136C, Millipore), in all cases diluted at 1:400 in buffer $\mathrm{G}$ for $2 \mathrm{~h}$ at room temperature.

11 Finally, the sections were mounted with a medium containing $0.1 \%$ 4', 6-diamidine-2'-

12 phenylindole (DAPI, Sigma), 1, 4-diazabicyclo [2, 2, 2] octane (Sigma) and 50 or 80\%

13 glycerol in $50 \mathrm{mM}$ Tris- $\mathrm{HCl}(\mathrm{pH} 8.0)$.

For morphological analysis of dendrites, mice were perfused with 4\% PFA in 0.1

M PB (pH 7.4). The brains were postfixed in the same fixative for $24 \mathrm{~h}$ at $4^{\circ} \mathrm{C}$, and equilibrated with $25 \%$ sucrose-PBS overnight at $4^{\circ} \mathrm{C}$. The brains were cut into $200-\mu \mathrm{m}$ coronal sections using a vibratome (DTK-1000, D.S.K.). The free-floating sections were permeabilized and blocked in buffer $\mathrm{G}$ for $1 \mathrm{~h}$ at room temperature. They were then incubated with primary antibodies, rat monoclonal anti-GFP (Nacalai Tesque, GF090R) at 1:2000 and rabbit polyclonal anti-tRFP (Evrogen, AB233) at 1:2000, in buffer G overnight at $4{ }^{\circ} \mathrm{C}$. The sections were washed three times with $0.1 \%$ Triton $\mathrm{X}-100$ in PBS (PBST) for $1 \mathrm{~h}$, and incubated with secondary antibodies in buffer $\mathrm{G}$ overnight at $4{ }^{\circ} \mathrm{C}$. The sections were then washed three times with PBST for $1 \mathrm{~h}$ and mounted with DAPIcontaining mounting medium.

Cultured cells were fixed with 4\% PFA in PBS for 10 min at room temperature, washed three times with PBS for 10 min, permeabilized, and blocked in buffer G. The cells were then incubated overnight at $4^{\circ} \mathrm{C}$ in buffer $\mathrm{G}$ with the following antibodies: mouse monoclonal anti-Tuj1 (R\&D Systems, MAB1195) at 1:1000, rabbit polyclonal 
1 anti-histone H2AX phosphor Ser139 (Active Motif, AR-0149-10) at 1:200, and rabbit

2 polyclonal anti 5-hydroxymethylcytosine (Active Motif, 39769) at 1:20000. For 5hmC

3 immunostaining, the cells were incubated with $1 \mathrm{M} \mathrm{HCl}$ for $30 \mathrm{~min}$ at $37^{\circ} \mathrm{C}$ and washed

4 three times with PBS for $30 \mathrm{~min}$ before permeabilization. Primary antibodies were

5 detected by incubation for $2 \mathrm{~h}$ at room temperature in buffer $\mathrm{G}$ with the following

6 secondary antibodies: Alexa488-conjugated anti rabbit IgG (A-11034, Invitrogen) at

7 1:400 and Cy3-conjugated anti-mouse IgG (AP192C, Millipore) at 1:400. The cells were

8 mounted with DAPI-containing mounting medium.

\section{Image analysis}

11 Fluorescence images were obtained by confocal microscopy (ECLIPSE FN with EZ-C1;

12 Nikon) with $10 \times / 0.3,20 \times / 0.75$, and $40 \times / 0.95$ objective lenses (Nikon). All images were 13 imported into Image J to adjust brightness and contrast. To acquire images of $\gamma \mathrm{H} 2 \mathrm{AX}$ and $14 \mathrm{XRCC1}$ in DAPI-stained nuclei, confocal z-stack images were collected at $0.5-\mu \mathrm{m}$ 15 intervals with a $40 \times$ objective lens. For focus counting, noise in the images was removed 16 by Gaussian filter and subtraction from the background, and foci were detected with the

17 "Find Maxima" tool in ImageJ. To obtain images of RFP-labeled apical and basal 18 dendrites in dorsal hippocampal CA1 regions, confocal z-stack images were collected at $191-\mu \mathrm{m}$ intervals through the $200-\mu \mathrm{m}$ sections using a $20 \times$ objective lens. Quantitative 20 analysis of dendrite morphology was performed using the ImageJ plug-ins Simple Neurite 21 Tracer and L-measure (Scorcioni et al, 2008).

\section{Immunoblot analysis}

24 Genomic DNA was extracted using a DNeasy Blood \& Tissue kit (QIAGEN). The DNA was eluted with $\mathrm{TE}$ buffer and stored at $-30^{\circ} \mathrm{C}$ until required. The genomic DNA was denatured in $20 \mathrm{mM}$ Tris- $\mathrm{HCl}(\mathrm{pH} 8.0)$ for $10 \mathrm{~min}$ at $98^{\circ} \mathrm{C}$ and chilled on ice. Serially diluted DNA samples $(1000,500,250,125 \mathrm{ng} / 200 \mu \mathrm{l})$ were blotted onto a positively 
1 charged nylon membrane (Millipore, INYC00010) using a Bio-Dot slot blot apparatus

2 (Bio-Rad). The membrane was air-dried, and UV-crosslinked using a CL-1000

3 Ultraviolet Crosslinker (UVP). The membrane was stained with $0.02 \%$ methylene blue

4 (Nacalai Tesque) for $30 \mathrm{~min}$ at room temperature as a loading control. The membrane

5 was then washed with Tris-buffered saline containing $0.1 \%$ Tween-20 (TBS-T) and

6 blocked in 5\% nonfat dry milk (Cell Signaling Technology, \#9999) diluted with TBS-T

7 for $1 \mathrm{~h}$ at room temperature. The membrane was incubated with the following primary

8 antibodies diluted in 5\% nonfat dry milk/TBS-T overnight at $4{ }^{\circ} \mathrm{C}$ : rabbit polyclonal anti-

9 5-hydroxymethylcytosine antibody (Active Motif, 39769) at 1:5000 and mouse

10 monoclonal anti-5-methylcytosine antibody (Active Motif, 39649) at 1:2000. Primary

11 antibodies were detected by incubation with the following secondary antibodies diluted

12 in 5\% skim milk in TBS-T for $2 \mathrm{~h}$ at room temperature: peroxidase-conjugated anti-rabbit

13 IgG antibody (Jackson ImmunoResearch, 711-035-152) at 1:5000 and peroxidase-

14 conjugated anti-mouse IgG (Nacalai Tesque, 01803-44) at 1:5000. The signal was

15 visualized by chemiluminescence with ECL Select western blotting detection reagent (GE

16 Healthcare) and imaged by LAS-3000UV mini (Fujifilm).

\section{RNA seq analysis}

19 Total RNA was extracted from P15 Pol $\beta^{f l / f l}$ and Nex-Cre/Pol $\beta^{f l f l}$ hippocampus using an

20 RNeasy Plus Mini Kit (QIAGEN) following the manufacturer's procedure. Library

21 preparation was performed using a TruSeq stranded mRNA sample prep kit (Illumina) according to the manufacturer's instructions. Whole-transcriptome sequencing was applied to the RNA samples with an Illumina HiSeq 2500 platform in a 75-base singleend mode. Illumina Casava ver.1.8.2 software was used for base calling. Sequenced reads were mapped to the mouse reference genome sequences (mm10) using TopHat ver. 2.0.13

26 in combination with Bowtie2 ver. 2.2.3 and SAMtools ver. 0.1.19. The number of

27 fragments per kilobase of exon per million mapped fragments (FPKMs) was calculated 
1 using Cufflinks ver. 2.2.1. Differentially expressed genes were defined by fold change >

$21.2, \mathrm{p}<0.05(\mathrm{n}=3)$. Functional annotation and pathway analysis were performed with

3 Ingenuity pathway analysis (QIAGEN). Correlation analysis of expression profiles was

4 performed with the Illumina correlation engine software (Illumina).

\section{Behavioral test}

7 Behavioral tests were carried out at Institute for Comprehensive Medical Science, Fujita

8 Health University (Joint Usage / Research Center for Genes, Brain and Behavior

9 accredited by MEXT). The comprehensive behavioral test was performed as described

10 previously (Shoji et al, 2018) with adult (> 3 month) Nex-Cre/Pol/ $\beta^{f l f l}$ mice and their

11 littermate controls. In brief, the Barnes maze test was performed with a white circular

12 surface, $1.0 \mathrm{~m}$ in diameter, with 12 holes equally spaced around the perimeter and

13 elevated $75 \mathrm{~cm}$ from the floor. A black Plexiglas escape box was located under one of the

14 holes and represented the target. The location of the target was consistent for each mouse

15 but randomized between mice. The visual cues were in the four corners of the experimental room. One or two trials per day were performed. The number of errors, latency to reach the target, and distance traveled before mice first reached their target were automatically calculated by image analysis. One day or one month after the last training session, a probe test was performed without the escape box for $3 \mathrm{~min}$, and time spent around each hole was measured and the ratio of time spent around the target / all

21 holes was quantified.

In conditioning session of contextual and cued fear-conditioning test, each mouse was placed in a transparent acrylic chamber with a stainless steel grid floor (O'Hara \& Co.) and allowed to explore for $2 \mathrm{~min}$. White noise ( $55 \mathrm{~dB})$ was then presented for $30 \mathrm{sec}$ as a conditioned stimulus (CS). A mild footshock $(0.3 \mathrm{~mA}, 2 \mathrm{sec})$ was presented as an unconditioned stimulus (UCS) during the last $2 \mathrm{sec}$ of the CS. Three CS-UCS

27 pairings were presented with a 2-min interval. One day or one month after the 
1 conditioning session, contest tests were conducted in the same chamber as conditioning.

2 Cued tests with altered context were then conducted in a triangular and white opaque

3 chamber which was located in a different room. In each test, freezing percentage and

4 distance traveled in 1 min were quantified.

In the elevated plus maze, each mouse was placed in the central square of the

6 maze, which consisted of two open arms $(25 \times 5 \mathrm{~cm})$ and two closed arms $(25 \times 5 \mathrm{~cm}$,

7 with 15-cm-high transparent walls), and allowed to explore for $10 \mathrm{~min}$. The number of

8 total entries into the arms, percentage of entries into the open arms, and percentage of

9 time spent in the open arms were quantified.

\section{Statistical analysis}

12 In statistical analysis, the number of samples analyzed is given for each experiment.

13 Significant differences were determined with Student's t-test, one-way ANOVA with

14 Tukey's post-hoc test for multiple comparisons, or repeated-measures ANOVA. All

15 statistical values are presented as mean value \pm SEM. All data were analyzed using Excel

162013 (Microsoft), StatView 5.0.1 software (SAS Institute), and JMP (SAS Institute). 


\section{Acknowledgments}

2 We are grateful to Drs. K.A. Nave for the Nex-Cre mice, and to K. Rajewsky for Pol $\beta$

3 flox mice. This work was supported by MEXT KAKENHI on Dynamic regulation of

4 brain function by Scrap \& Build system (No. 16H06460) to N.Y., by JSPS KAKENHI

5 Grant Nos. 15K14350 and 17K07109 to N.S., 16H06276 (AdAMS) to N.S. and T.M., and 6 by AMED-CREST to T.Y.

7

\section{Author contributions}

9 T.M., T.Y., N.Y. and N.S. conceived and designed the research project. A.U., K.O., T.H., 10 S.H. and N.S. performed the experiments and analyzed the data. A.U., T.M., T.Y., N.Y.

11 and N.S. wrote the manuscript, which was discussed and critically edited by all coauthors.

13 Declaration of interests

14 The authors declare no competing financial interests. 


\section{References}

2 Alt FW, Zhang Y, Meng FL, Guo C, Schwer B (2013) Mechanisms of programmed DNA

3 lesions and genomic instability in the immune system. Cell 152: 417-29

4 Beranek DT (1990) Distribution of methyl and ethyl adducts following alkylation with 5 monofunctional alkylating agents. Mutat Res 231: 11-30

6 Blaschke K, Ebata KT, Karimi MM, Zepeda-Martinez JA, Goyal P, Mahapatra S, Tam A,

7 Laird DJ, Hirst M, Rao A, Lorincz MC, Ramalho-Santos M (2013) Vitamin C induces

8 Tet-dependent DNA demethylation and a blastocyst-like state in ES cells. Nature 500:

$9222-6$

10 Bundo M, Toyoshima M, Okada Y, Akamatsu W, Ueda J, Nemoto-Miyauchi T, Sunaga F, 11 Toritsuka M, Ikawa D, Kakita A, Kato M, Kasai K, Kishimoto T, Nawa H, Okano H, 12 Yoshikawa T, Kato T, Iwamoto K (2014) Increased 11 retrotransposition in the neuronal 13 genome in schizophrenia. Neuron 81: 306-13

14 Cai X, Evrony GD, Lehmann HS, Elhosary PC, Mehta BK, Poduri A, Walsh CA (2014) 15 Single-cell, genome-wide sequencing identifies clonal somatic copy-number variation in 16 the human brain. Cell Rep 8: 1280-9

17 Caldecott KW (2003) XRCC1 and DNA strand break repair. DNA Repair (Amst) 2: 955$18 \quad 69$

19 Capitano F, Gargiuli C, Angerilli A, Maccaroni K, Pelliccia F, Mele A, Camilloni G 20 (2016) RNA polymerase I transcription is modulated by spatial learning in different brain 21 regions. J Neurochem 136: 706-716

22 Cheng J, Guo S, Chen S, Mastriano SJ, Liu C, D'Alessio AC, Hysolli E, Guo Y, Yao H, 23 Megyola CM, Li D, Liu J, Pan W, Roden CA, Zhou XL, Heydari K, Chen J, Park IH, 24 Ding Y, Zhang Y et al. (2013) An extensive network of TET2-targeting MicroRNAs regulates malignant hematopoiesis. Cell Rep 5: 471-81

26 Chong MJ, Murray MR, Gosink EC, Russell HR, Srinivasan A, Kapsetaki M, Korsmeyer 27 SJ, McKinnon PJ (2000) Atm and Bax cooperate in ionizing radiation-induced apoptosis 28 in the central nervous system. Proc Natl Acad Sci U S A 97: 889-94

29 Cohen S, Gabel HW, Hemberg M, Hutchinson AN, Sadacca LA, Ebert DH, Harmin DA, 30 Greenberg RS, Verdine VK, Zhou Z, Wetsel WC, West AE, Greenberg ME (2011) 31 Genome-wide activity-dependent $\mathrm{MeCP} 2$ phosphorylation regulates nervous system 
1 development and function. Neuron 72: 72-85

2 Cortellino S, Xu J, Sannai M, Moore R, Caretti E, Cigliano A, Le Coz M, Devarajan K, 3 Wessels A, Soprano D, Abramowitz LK, Bartolomei MS, Rambow F, Bassi MR, Bruno 4 T, Fanciulli M, Renner C, Klein-Szanto AJ, Matsumoto Y, Kobi D et al. (2011) Thymine 5 DNA glycosylase is essential for active DNA demethylation by linked deamination-base 6 excision repair. Cell 146: 67-79

7 Cortázar D, Kunz C, Selfridge J, Lettieri T, Saito Y, MacDougall E, Wirz A, Schuermann 8 D, Jacobs AL, Siegrist F, Steinacher R, Jiricny J, Bird A, Schär P (2011) Embryonic lethal 9 phenotype reveals a function of TDG in maintaining epigenetic stability. Nature 470: 419$10 \quad 423$

11 Deans B, Griffin CS, Maconochie M, Thacker J (2000) Xrcc2 is required for genetic 12 stability, embryonic neurogenesis and viability in mice. EMBO J 19: 6675-85

13 Dobbin MM, Madabhushi R, Pan L, Chen Y, Kim D, Gao J, Ahanonu B, Pao P-C, Qiu Y, 14 Zhao Y, Tsai L-H (2013) SIRT1 collaborates with ATM and HDAC1 to maintain genomic 15 stability in neurons. Nature Neuroscience 16: 1008-1015

16 El-Khamisy SF, Masutani M, Suzuki H, Caldecott KW (2003) A requirement for PARP171 for the assembly or stability of XRCC1 nuclear foci at sites of oxidative DNA damage. $18 \quad$ Nucleic Acids Res 31: 5526-33

19 Feng J, Zhou Y, Campbell SL, Le T, Li E, Sweatt JD, Silva AJ, Fan G (2010) Dnmt1 and 20 Dnmt3a maintain DNA methylation and regulate synaptic function in adult forebrain 21 neurons. Nat Neurosci 13: 423-30

22 Flavell SW, Greenberg ME (2008) Signaling mechanisms linking neuronal activity to 23 gene expression and plasticity of the nervous system. Annu Rev Neurosci 31: 563-90

24 Fromer M, Pocklington AJ, Kavanagh DH, Williams HJ, Dwyer S, Gormley P, Georgieva 25 L, Rees E, Palta P, Ruderfer DM, Carrera N, Humphreys I, Johnson JS, Roussos P, Barker 26 DD, Banks E, Milanova V, Grant SG, Hannon E, Rose SA et al. (2014) De novo mutations 27 in schizophrenia implicate synaptic networks. Nature 506: 179-84

28 Fukuchi-Shimogori T, Grove EA (2001) Neocortex patterning by the secreted signaling 29 molecule FGF8. Science 294: 1071-4

30 Gao Y, Sun Y, Frank KM, Dikkes P, Fujiwara Y, Seidl KJ, Sekiguchi JM, Rathbun GA, 
1 Swat W, Wang J, Bronson RT, Malynn BA, Bryans M, Zhu C, Chaudhuri J, Davidson L,

2 Ferrini R, Stamato T, Orkin SH, Greenberg ME et al. (1998) A critical role for DNA end-

3 joining proteins in both lymphogenesis and neurogenesis. Cell 95: 891-902

4 Golshani P, Hutnick L, Schweizer F, Fan G (2005) Conditional Dnmt1 deletion in dorsal

5 forebrain disrupts development of somatosensory barrel cortex and thalamocortical long-

6 term potentiation. Thalamus Relat Syst 3: 227-233

7 Gontier G, Iyer M, Shea JM, Bieri G, Wheatley EG, Ramalho-Santos M, Villeda SA

8 (2018) Tet2 Rescues Age-Related Regenerative Decline and Enhances Cognitive

9 Function in the Adult Mouse Brain. Cell Rep 22: 1974-1981

10 Gu Y, Sekiguchi J, Gao Y, Dikkes P, Frank K, Ferguson D, Hasty P, Chun J, Alt FW

11 (2000) Defective embryonic neurogenesis in Ku-deficient but not DNA-dependent

12 protein kinase catalytic subunit-deficient mice. Proc Natl Acad Sci U S A, pp 2668-73.

13 He YF, Li BZ, Li Z, Liu P, Wang Y, Tang Q, Ding J, Jia Y, Chen Z, Li L, Sun Y, Li X, Dai 14 Q, Song CX, Zhang K, He C, Xu GL (2011) Tet-mediated formation of 515 carboxylcytosine and its excision by TDG in mammalian DNA. Science 333: 1303-7

16 Hysolli E, Tanaka Y, Su J, Kim K-Y, Zhong T, Janknecht R, Zhou X-L, Geng L, Qiu C,

17 Pan X, Jung Y-W, Cheng J, Lu J, Zhong M, Weissman SM, Park I-H (2016) Regulation 18 of the DNA Methylation Landscape in Human Somatic Cell Reprogramming by the miR-

1929 Family. Stem Cell Reports 7: 43-54

20 Inestrosa NC, Varela-Nallar L (2015) Wnt signalling in neuronal differentiation and 21 development. Cell Tissue Res 359: 215-23

22 Iossifov I, O'Roak BJ, Sanders SJ, Ronemus M, Krumm N, Levy D, Stessman HA, 23 Witherspoon KT, Vives L, Patterson KE, Smith JD, Paeper B, Nickerson DA, Dea J, Dong 24 S, Gonzalez LE, Mandell JD, Mane SM, Murtha MT, Sullivan CA et al. (2014) The contribution of de novo coding mutations to autism spectrum disorder. Nature 515: 21626 21

27 Ito S, D'Alessio AC, Taranova OV, Hong K, Sowers LC, Zhang Y (2010) Role of Tet 28 proteins in $5 \mathrm{mC}$ to $5 \mathrm{hmC}$ conversion, ES-cell self-renewal and inner cell mass 29 specification. Nature 466: 1129-33

30 Ito S, Shen L, Dai Q, Wu SC, Collins LB, Swenberg JA, He C, Zhang Y (2011) Tet 31 proteins can convert 5-methylcytosine to 5-formylcytosine and 5-carboxylcytosine. 
2 Jimenez JC, Su K, Goldberg AR, Luna VM, Biane JS, Ordek G, Zhou P, Ong SK, Wright

3 MA, Zweifel L, Paninski L, Hen R, Kheirbek MA (2018) Anxiety Cells in a

4 Hippocampal-Hypothalamic Circuit. Neuron 97: 670-683.e6

5 Kaas GA, Zhong C, Eason DE, Ross DL, Vachhani RV, Ming GL, King JR, Song H,

6 Sweatt JD (2013) TET1 controls CNS 5-methylcytosine hydroxylation, active DNA

7 demethylation, gene transcription, and memory formation. Neuron 79: 1086-93

8 Kim JJ, Fanselow MS (1992) Modality-specific retrograde amnesia of fear. Science 256:

$9 \quad 675-7$

10 Kolodkin AL, Tessier-Lavigne M (2011) Mechanisms and molecules of neuronal wiring:

11 a primer. Cold Spring Harb Perspect Biol 3

12 Koopmans G, Blokland A, van Nieuwenhuijzen P, Prickaerts J (2003) Assessment of 13 spatial learning abilities of mice in a new circular maze. Physiol Behav 79: 683-93

14 Kulkarni A, McNeill DR, Gleichmann M, Mattson MP, Wilson DM, 3rd (2008) XRCC1 15 protects against the lethality of induced oxidative DNA damage in nondividing neural 16 cells. Nucleic Acids Res 36: 5111-21

17 Kuzminov A (2001) Single-strand interruptions in replicating chromosomes cause 18 double-strand breaks. Proc Natl Acad Sci U S A 98: 8241-6

19 Lee Y, Chong MJ, McKinnon PJ (2001) Ataxia telangiectasia mutated-dependent 20 apoptosis after genotoxic stress in the developing nervous system is determined by 21 cellular differentiation status. J Neurosci 21: 6687-93

22 Lee Y, Katyal S, Li Y, El-Khamisy SF, Russell HR, Caldecott KW, McKinnon PJ (2009)

23 The genesis of cerebellar interneurons and the prevention of neural DNA damage require 24 XRCC1. Nat Neurosci 12: 973-80

25 Li X, Wei W, Zhao QY, Widagdo J, Baker-Andresen D, Flavell CR, D’Alessio A, Zhang 26 Y, Bredy TW (2014) Neocortical Tet3-mediated accumulation of 527 hydroxymethylcytosine promotes rapid behavioral adaptation. Proc Natl Acad Sci U S A, 28 pp 7120-5.

29 Lieber MR (2010) The mechanism of double-strand DNA break repair by the 30 nonhomologous DNA end-joining pathway. Annu Rev Biochem 79: 181-211 
1 Lindahl T, Wood RD (1999) Quality control by DNA repair. Science 286: 1897-905

2 Lister R, Mukamel EA, Nery JR, Urich M, Puddifoot CA, Johnson ND, Lucero J, Huang 3 Y, Dwork AJ, Schultz MD, Yu M, Tonti-Filippini J, Heyn H, Hu S, Wu JC, Rao A, Esteller 4 M, He C, Haghighi FG, Sejnowski TJ et al. (2013) Global epigenomic reconfiguration 5 during mammalian brain development. Science 341: 1237905

6 Lodato MA, Woodworth MB, Lee S, Evrony GD, Mehta BK, Karger A, Chittenden TW, 7 D'Gama AM, Cai X, Luquette LJ, Lee E, Park PJ, Walsh CA (2015) Somatic mutation in 8 single human neurons tracks developmental and transcriptional history. Science 350: 94998

10 Lu T, Pan Y, Kao SY, Li C, Kohane I, Chan J, Yankner BA (2004) Gene regulation and 11 DNA damage in the ageing human brain. Nature 429: 883-91

12 Luo W, Mizuno H, Iwata R, Nakazawa S, Yasuda K, Itohara S, Iwasato T (2016) 13 Supernova: A Versatile Vector System for Single-Cell Labeling and Gene Function 14 Studies. Scientific Reports 6: 35747

15 Madabhushi R, Pan L, Tsai LH (2014) DNA damage and its links to neurodegeneration. 16 Neuron 83: 266-282

17 McConnell MJ, Lindberg MR, Brennand KJ, Piper JC, Voet T, Cowing-Zitron C, 18 Shumilina S, Lasken RS, Vermeesch J, Hall IM, Gage FH (2013) Mosaic Copy Number 19 Variation in Human Neurons. Science 342: 632-7

20 McConnell MJ, Moran JV, Abyzov A, Akbarian S, Bae T, Cortes-Ciriano I, Erwin JA, 21 Fasching L, Flasch DA, Freed D, Ganz J, Jaffe AE, Kwan KY, Kwon M, Lodato MA, 22 Mills RE, Paquola ACM, Rodin RE, Rosenbluh C, Sestan N et al. (2017) Intersection of 23 diverse neuronal genomes and neuropsychiatric disease: The Brain Somatic Mosaicism 24 Network. Science 356

25 McKinnon PJ (2013) Maintaining genome stability in the nervous system. Nat Neurosci 26 16: 1523-9

27 Mizuno H, Luo W, Tarusawa E, Saito YM, Sato T, Yoshimura Y, Itohara S, Iwasato T 28 (2014) NMDAR-Regulated Dynamics of Layer 4 Neuronal Dendrites during 29 Thalamocortical Reorganization in Neonates. Neuron 82: 365-379

30 Moore LD, Le T, Fan G (2013) DNA methylation and its basic function. 
2 Moretti P, Levenson JM, Battaglia F, Atkinson R, Teague R, Antalffy B, Armstrong D, 3 Arancio O, Sweatt JD, Zoghbi HY (2006) Learning and memory and synaptic plasticity

4 are impaired in a mouse model of Rett syndrome. J Neurosci 26: 319-27

5 Niwa H, Yamamura K, Miyazaki J (1991) Efficient selection for high-expression 6 transfectants with a novel eukaryotic vector. Gene 108: 193-9

7 Nowak R, Woszczynski M, Siedlecki JA (1990) Changes in the DNA polymerase beta 8 gene expression during development of lung, brain, and testis suggest an involvement of 9 the enzyme in DNA recombination. Exp Cell Res 191: 51-6

10 Onishi K, Uyeda A, Shida M, Hirayama T, Yagi T, Yamamoto N, Sugo N (2017) Genome 11 Stability by DNA Polymerase beta in Neural Progenitors Contributes to Neuronal 12 Differentiation in Cortical Development. J Neurosci 37: 8444-8458

13 Poduri A, Evrony GD, Cai X, Walsh CA (2013) Somatic mutation, genomic variation, 14 and neurological disease. Science 341: 1237758

15 Pulvers JN, Huttner WB (2009) Brcal is required for embryonic development of the 16 mouse cerebral cortex to normal size by preventing apoptosis of early neural progenitors.

17 Development 136: 1859-68

18 Rao KS, Annapurna VV, Raji NS (2001) DNA polymerase-beta may be the main player

19 for defective DNA repair in aging rat neurons. Ann N Y Acad Sci 928: 113-20

20 Rehen SK, Yung YC, McCreight MP, Kaushal D, Yang AH, Almeida BS, Kingsbury MA, 21 Cabral KM, McConnell MJ, Anliker B, Fontanoz M, Chun J (2005) Constitutional 22 aneuploidy in the normal human brain. J Neurosci 25: 2176-80

23 Rogakou EP, Boon C, Redon C, Bonner WM (1999) Megabase chromatin domains 24 involved in DNA double-strand breaks in vivo. J Cell Biol 146: 905-16

25 Rogakou EP, Pilch DR, Orr AH, Ivanova VS, Bonner WM (1998) DNA double-stranded 26 breaks induce histone H2AX phosphorylation on serine 139. J Biol Chem 273: 5858-68

27 Ross W, Rowe T, Glisson B, Yalowich J, Liu L (1984) Role of topoisomerase II in 28 mediating epipodophyllotoxin-induced DNA cleavage. Cancer Res 44: 5857-60

29 Rudenko A, Dawlaty MM, Seo J, Cheng AW, Meng J, Le T, Faull KF, Jaenisch R, Tsai 
1 LH (2013) Tet1 is critical for neuronal activity-regulated gene expression and memory

2 extinction. Neuron 79: 1109-22

3 Sanosaka T, Imamura T, Hamazaki N, Chai M, Igarashi K, Ideta-Otsuka M, Miura F, Ito 4 T, Fujii N, Ikeo K, Nakashima K (2017) DNA Methylome Analysis Identifies

5 Transcription Factor-Based Epigenomic Signatures of Multilineage Competence in

6 Neural Stem/Progenitor Cells. Cell Rep 20: 2992-3003

7 Schuermann D, Weber AR, Schar P (2016) Active DNA demethylation by DNA repair:

8 Facts and uncertainties. DNA Repair (Amst) 44: 92-102

9 Schultz LB, Chehab NH, Malikzay A, Halazonetis TD (2000) p53 binding protein 1

10 (53BP1) is an early participant in the cellular response to DNA double-strand breaks. $J$

11 Cell Biol 151: 1381-90

12 Scorcioni R, Polavaram S, Ascoli GA (2008) L-Measure: a web-accessible tool for the 13 analysis, comparison and search of digital reconstructions of neuronal morphologies. Nat 14 Protoc 3: 866-76

15 Sharma A, Klein SS, Barboza L, Lohdi N, Toth M (2016) Principles Governing DNA 16 Methylation during Neuronal Lineage and Subtype Specification. J Neurosci 36: 1711$17 \quad 22$

18 Shoji H, Irino Y, Yoshida M, Miyakawa T (2018) Behavioral effects of long-term oral 19 administration of aluminum ammonium sulfate in male and female C57BL/6J mice. 20 Neuropsychopharmacol Rep 38: 18-36

21 Simmons RK, Stringfellow SA, Glover ME, Wagle AA, Clinton SM (2013) DNA methylation markers in the postnatal developing rat brain. Brain Res 1533: 26-36

Sobol RW, Horton JK, Kuhn R, Gu H, Singhal RK, Prasad R, Rajewsky K, Wilson SH 24 (1996) Requirement of mammalian DNA polymerase-beta in base-excision repair. Nature 25 379: $183-6$

26 Stroud H, Su SC, Hrvatin S, Greben AW, Renthal W, Boxer LD, Nagy MA, Hochbaum 27 DR, Kinde B, Gabel HW, Greenberg ME (2017) Early-Life Gene Expression in Neurons 28 Modulates Lasting Epigenetic States. Cell 171: 1151-1164.e16

29 Sugo N, Aratani Y, Nagashima Y, Kubota Y, Koyama H (2000) Neonatal lethality with 30 abnormal neurogenesis in mice deficient in DNA polymerase beta. EMBO J 19: 1397- 
2 Sugo N, Niimi N, Aratani Y, Masutani M, Suzuki H, Koyama H (2007) Decreased PARP-

31 levels accelerate embryonic lethality but attenuate neuronal apoptosis in DNA

4 polymerase beta-deficient mice. Biochem Biophys Res Commun 354: 656-61

5 Sugo N, Niimi N, Aratani Y, Takiguchi-Hayashi K, Koyama H (2004) p53 Deficiency

6 rescues neuronal apoptosis but not differentiation in DNA polymerase beta-deficient mice.

$7 \quad$ Mol Cell Biol 24: 9470-7

8 Sykora P, Misiak M, Wang Y, Ghosh S, Leandro GS, Liu D, Tian J, Baptiste BA, Cong

9 WN, Brenerman BM, Fang E, Becker KG, Hamilton RJ, Chigurupati S, Zhang Y, Egan

10 JM, Croteau DL, Wilson DM, 3rd, Mattson MP, Bohr VA (2015) DNA polymerase beta

11 deficiency leads to neurodegeneration and exacerbates Alzheimer disease phenotypes.

12 Nucleic Acids Res 43: 943-59

13 Tabata H, Nakajima K (2001) Efficient in utero gene transfer system to the developing 14 mouse brain using electroporation: visualization of neuronal migration in the developing 15 cortex. Neuroscience 103: 865-72

16 Tahiliani M, Koh KP, Shen Y, Pastor WA, Bandukwala H, Brudno Y, Agarwal S, Iyer LM, 17 Liu DR, Aravind L, Rao A (2009) Conversion of 5-Methylcytosine to 518 Hydroxymethylcytosine in Mammalian DNA by MLL Partner TET1. Science 324: 930195

20 Tomita K, Kubo K, Ishii K, Nakajima K (2011) Disrupted-in-Schizophrenia-1 (Disc1) is 21 necessary for migration of the pyramidal neurons during mouse hippocampal 22 development. Hum Mol Genet 20: 2834-45

23 Weber AR, Krawczyk C, Robertson AB, Kuśnierczyk A, Vågbø CB, Schuermann D, 24 Klungland A, Schär P (2016) Biochemical reconstitution of TET1-TDG-BER-dependent 25 active DNA demethylation reveals a highly coordinated mechanism. Nature 26 Communications 7

27 Wei PC, Chang AN, Kao J, Du Z, Meyers RM, Alt FW, Schwer B (2016) Long Neural 28 Genes Harbor Recurrent DNA Break Clusters in Neural Stem/Progenitor Cells. Cell 164: $29 \quad 644-55$

30 Williams JT, Christie MJ, Manzoni O (2001) Cellular and synaptic adaptations mediating 31 opioid dependence. Physiol Rev 81: 299-343 
1 Wilson DM, 3rd, McNeill DR (2007) Base excision repair and the central nervous system.

2 Neuroscience 145: 1187-200

3 Wilson SH, Sobol RW, Beard WA, Horton JK, Prasad R, Berg BJV (2000) DNA

4 Polymerase $\beta$ and Mammalian Base Excision Repair.

5 Wu SC, Zhang Y (2010) Active DNA demethylation: many roads lead to Rome. Nat Rev

6 Mol Cell Biol 11: 607-20

7 Wu X, Zhang Y (2017) TET-mediated active DNA demethylation: mechanism, function 8 and beyond. Nat Rev Genet 18: 517-534

9 Yu H, Su Y, Shin J, Zhong C, Guo JU, Weng YL, Gao F, Geschwind DH, Coppola G, 10 Ming GL, Song H (2015) Tet3 regulates synaptic transmission and homeostatic plasticity 11 via DNA oxidation and repair. Nat Neurosci 18: 836-43

12 Zhou Z, Hong EJ, Cohen S, Zhao WN, Ho HY, Schmidt L, Chen WG, Lin Y, Savner E, 13 Griffith EC, Hu L, Steen JA, Weitz CJ, Greenberg ME (2006) Brain-specific 14 phosphorylation of $\mathrm{MeCP} 2$ regulates activity-dependent Bdnf transcription, dendritic 15 growth, and spine maturation. Neuron 52: 255-69

16 Zhu X, Girardo D, Govek EE, John K, Mellen M, Tamayo P, Mesirov JP, Hatten ME 17 (2016) Role of Tet1/3 Genes and Chromatin Remodeling Genes in Cerebellar Circuit 18 Formation. Neuron 89: 100-12 


\section{Figures and Figure Legends}

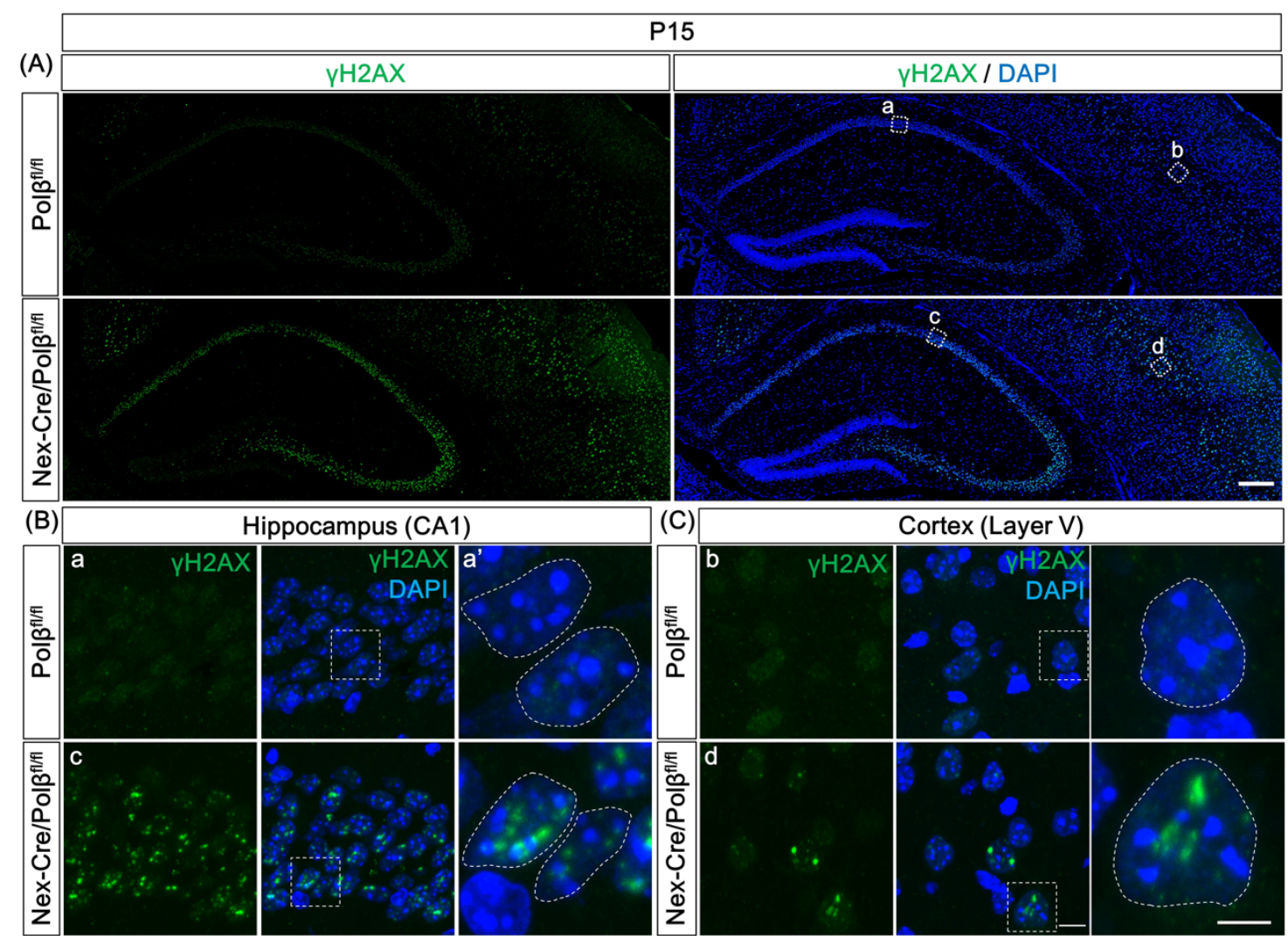

(D) $\square \mathrm{Pol}^{\mathrm{f} / \mathrm{fl}}$

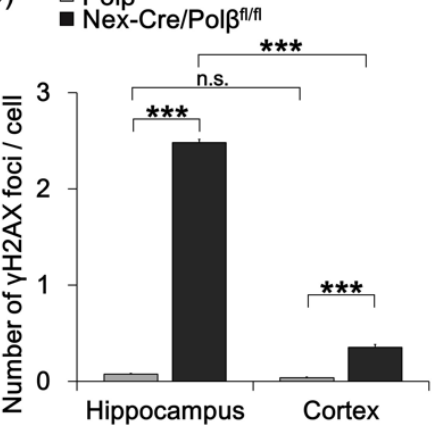

(E)

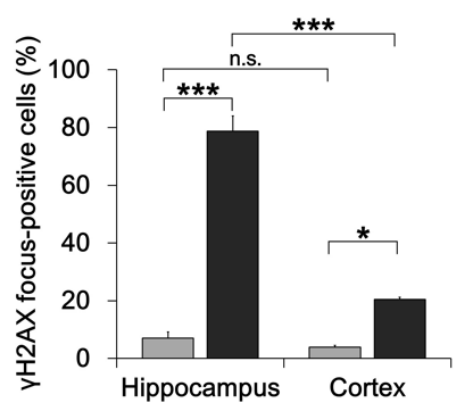

2 Fig. 1 Nex-Cre/Polfflfl mice exhibit DSBs in postnatal hippocampus and cortex.

3 (A) Immunohistochemistry was performed with anti- $\gamma \mathrm{H} 2 \mathrm{AX}$ antibody in P15 Nex-

$4 \quad C r e / P o l \beta^{f l f l}$ and Pol $\beta^{f l f l}$ hippocampus and cortex. Scale bar, $400 \mu \mathrm{m}$. (B, C) Magnified

5 images of the boxed areas in (A) including hippocampal CA1 pyramidal cell layer $(\mathrm{a}, \mathrm{c})$

6 and cortical layer V (b, d) are shown. Magnified images of the dashed-line boxed areas

7 in the center image are shown in the the rightmost images. The dashed lines in the

8 rightmost images mark the perimeter of the nucleus. Scale bars, 10 (the center) and $5 \mu \mathrm{m}$ 
1 (the right). (D, E) Histograms show quantitative analysis of the mean number of $\gamma \mathrm{H} 2 \mathrm{AX}$

2 foci in each nucleus (D) and percentage of $\gamma \mathrm{H} 2 \mathrm{AX}$ foci-positive cells (E) in hippocampus

3 and cortex of Nex-Cre/Pol $\beta^{f l f l}(\mathrm{n}=492$ cells, $\mathrm{n}=666$ cells $)$ and $P$ ol $\beta^{f l / f l}(\mathrm{n}=513$ cells, $\mathrm{n}$

$4=791$ cells) mice. Data are the mean \pm SEM from three different brains. Significant

5 difference: $* \mathrm{p}<0.05$ and $* * * \mathrm{p}<0.001$, ANOVA with Tukey's post-hoc test.

6 


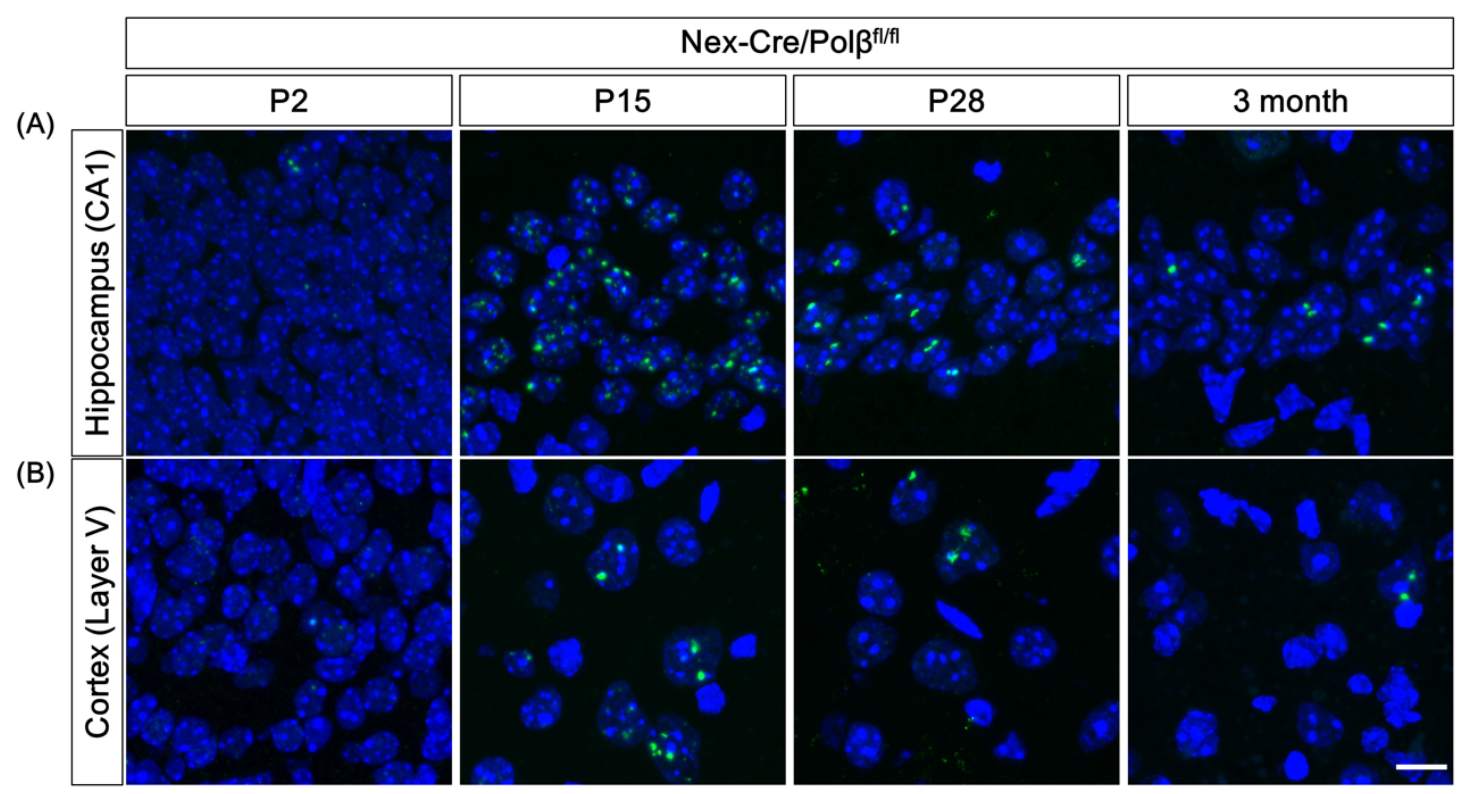

(C)

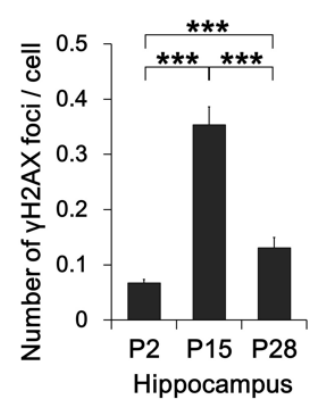

(E)

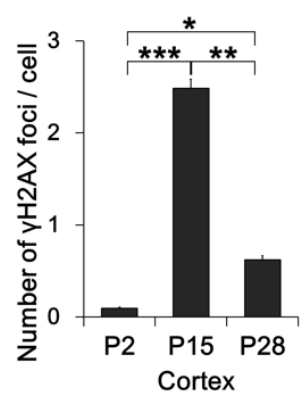

(F)

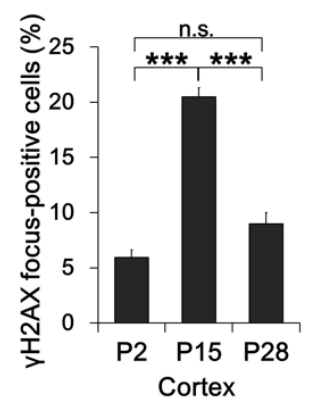

1 Fig. 2 DSB formation in Nex-Cre/Pol/ $\beta^{f l f l}$ mice transiently increases during postnatal

\section{2 development.}

3 (A, B) Immunohistochemistry was performed with anti- $\gamma \mathrm{H} 2 \mathrm{AX}$ antibody in Nex-

$4 C r e / P o l \beta^{f l f l}$ and Pol $\beta^{f l / f l}$ hippocampus (A) and cortex (B) at P2, P15, P28, and 3 months.

5 Scale bar, $10 \mu \mathrm{m}$. (C-F) Histograms show quantitative analysis of the mean number of $6 \gamma \mathrm{H} 2 \mathrm{AX}$ foci in each nucleus $(\mathrm{C}, \mathrm{E})$ and $\gamma \mathrm{H} 2 \mathrm{AX}$ foci-positive cells $(\mathrm{D}, \mathrm{F})$ in hippocampus

7 (C, D) and cortex (E, F) of Nex-Cre/Pol $\beta^{f l f l}$ mice at P2 ( $\mathrm{n}=1160$ cells, $\mathrm{n}=2155$ cells),

8 P15 ( $n=492$ cells, $n=690$ cells $)$, and P28 $(n=477$ cells, $n=620$ cells $)$. Data are the

9 mean \pm SEM from three independent experiments. Significant difference: ${ }^{*} \mathrm{p}<0.05,{ }^{*} \mathrm{p}$

$10<0.01$, and $* * * \mathrm{p}<0.001$, ANOVA with Tukey's post-hoc test. 


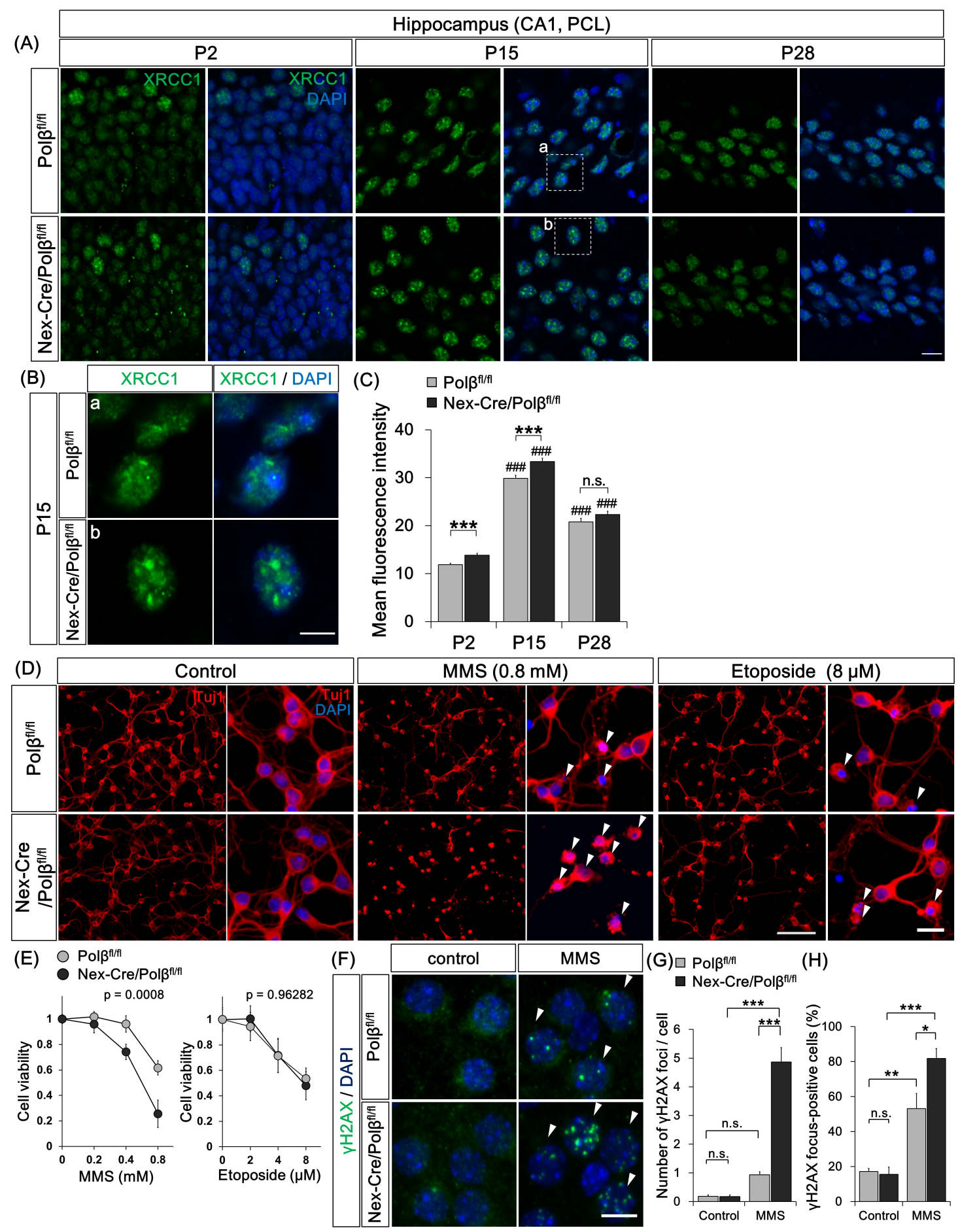

\section{Fig. 3 Pol $\beta$ is required for SSB repair in postmitotic neurons.}

2 (A) Immunohistochemistry was performed with anti-XRCC1 antibody in CA1 pyramidal

3 cell layers of Nex-Cre/Pol $\beta^{f l f l}$ and Pol $\beta^{f l / f l}$ hippocampus at P2, P15, and P28. Scale bar,

$410 \mu \mathrm{m}$. (B) Magnified images of the boxed areas in (A) are shown. Scale bar, $5 \mu \mathrm{m}$. (C)

5 Histogram shows the mean XRCC1 fluorescence intensity in DAPI-stained nuclei of Nex- 
$1 C r e / P o l \beta^{f l f l}(\mathrm{n}=576,295$, and 234 cells $)$ and $\operatorname{Pol}^{f l f l l}(\mathrm{n}=643,282$, and 256 cells $)$

2 hippocampal CA1 cells at P2, P15, and P28. Data are the mean \pm SEM. Significant

3 difference from Pol $f^{f l f l}$ mice: $* * * p<0.001$, ANOVA with Tukey's post-hoc test.

4 Significant difference between age groups: ${ }^{\# \#} \mathrm{p}<0.001$, ANOVA with Tukey's post-hoc 5 test. (D) Primary cultured neurons from E16.5 Nex-Cre/Pol $\beta^{f l / f l}$ or Pol $\beta^{f l / f l}$ cortex were 6 treated with MMS or etoposide for $1 \mathrm{~h}$ at 3-4 days in vitro (DIV), and fixed after $24 \mathrm{~h}$ 7 recovery. Immunocytochemistry was then performed with anti-Tuj1 antibody. 8 Arrowheads indicate dying pyknotic cells. Magnified images are shown in the right 9 panels. Scale bars, 100 and $20 \mu \mathrm{m}$. (E) Quantitative analysis of cell viability of Nex$10 C r e / P o l \beta^{f l f l}$ and Pol $\beta^{f l f l}$ cortical neurons treated with MMS or etoposide for $1 \mathrm{~h}$. Data are 11 mean \pm SEM from three independent experiments. Significant difference: $p$-values 12 (repeated measures ANOVA) are indicated. (F) Primary cultured neurons from E16.5 13 Nex-Cre/Pol $\beta^{f l f l}$ or Polfflfl cortex were treated with MMS for $1 \mathrm{~h}$ at 14 DIV and 14 immunocytochemistry was performed with anti- $\gamma \mathrm{H} 2 \mathrm{AX}$ antibody. Arrowheads indicate $15 \gamma \mathrm{H} 2 \mathrm{AX}$ focus-positive cells. $(\mathrm{G}, \mathrm{H})$ Histograms show quantitative analysis of the mean 16 number of $\gamma \mathrm{H} 2 \mathrm{AX}$ foci in each nucleus $(\mathrm{G})$ and the percentage of $\gamma \mathrm{H} 2 \mathrm{AX}$ focus-positive cells $(H)$. Data are mean \pm SEM from control or MMS-treated Nex-Cre/Pol $\beta^{f l f l}(\mathrm{n}=79$

18 cells, $\mathrm{n}=80$ cells $)$ and Polpllfl $(\mathrm{n}=71$ cells, $\mathrm{n}=86$ cells) neurons in three independent

19 experiments. Significant difference: $* p<0.05, * * p<0.01$, and $* * * p<0.001$, ANOVA with Tukey's post-hoc test. 

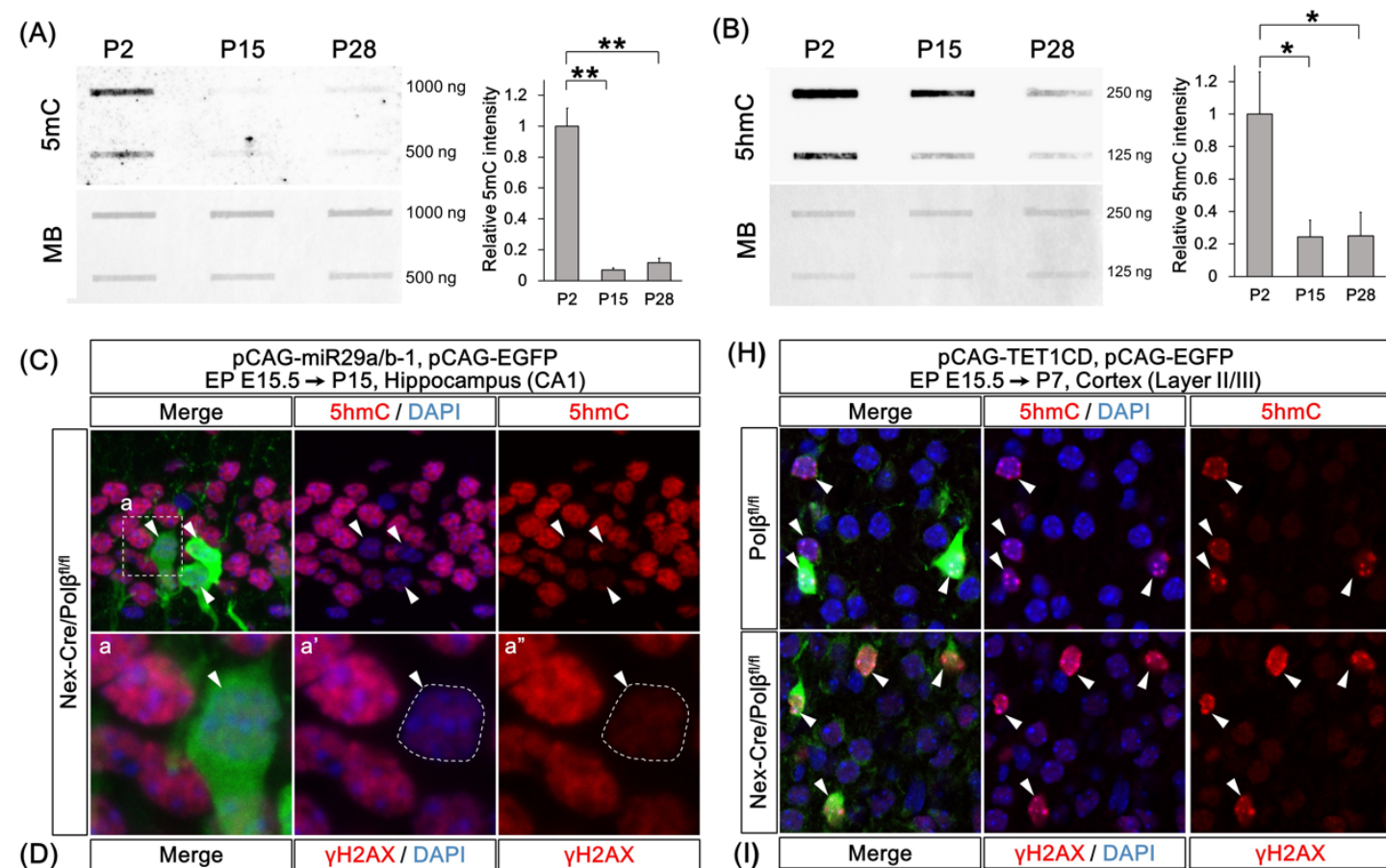

(D)

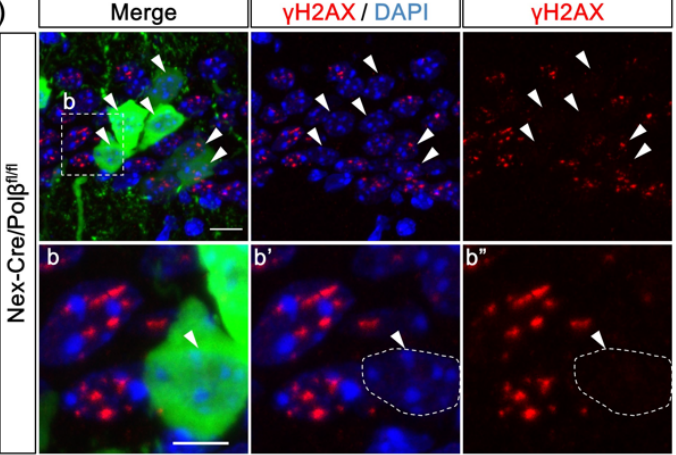

Nex-Cre/Pol $\beta^{\text {fl/t }}$

Nex-Cre/Pol $\beta^{f / f /}+\mathrm{miR} 29$

(E)

(F)

(G)
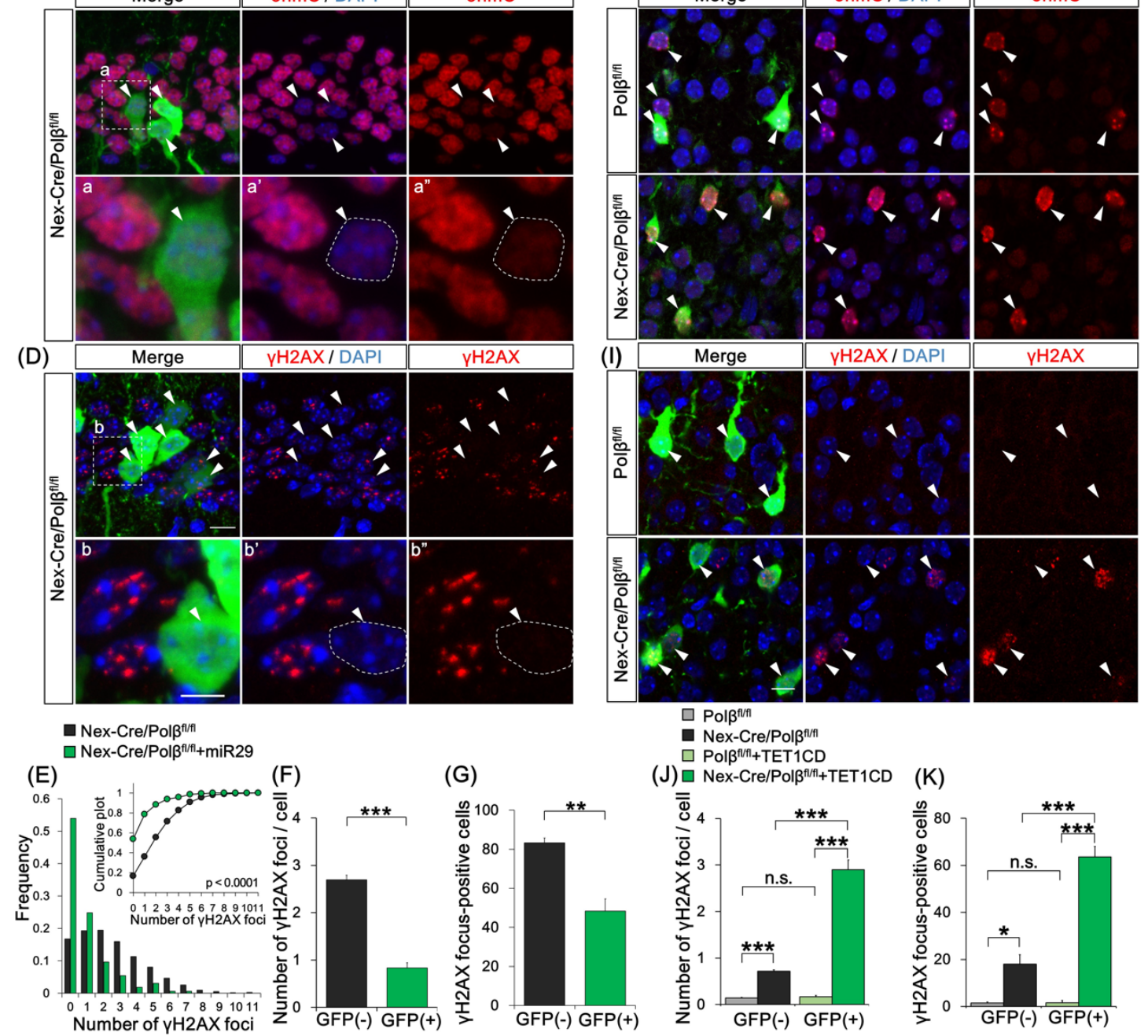

\section{$\square$ Polß $\beta^{\text {furf }}$}

- Nex-Cre/Pol $\beta^{\text {fl/f }}$

$\square$ Pol $\beta^{\mathrm{f} / 1+}+\mathrm{TET} 1 \mathrm{CD}$

(J) $\square$ Nex-Cre/Pol/ $\beta^{f / f+}+$ TET1CD (K)
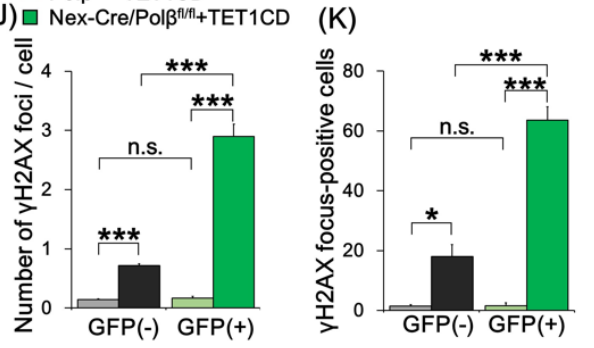

1 Fig. 4 Loss of Pol $\beta$ in active DNA demethylation causes DSBs in neurons.

2 (A, B) Immunoblot analyses show amounts of $5 \mathrm{mC}(\mathrm{A})$ and $5 \mathrm{hmC}(\mathrm{B})$ in genomic DNA

3 from P2, P15, and P28 Polf $f^{f l f l}$ hippocampus. The membranes were also stained with

4 methylene blue (MB) as a loading control. The relative intensity of $5 \mathrm{mC}$ and $5 \mathrm{hmC}$ was

5 quantified. Data are mean \pm SEM from three different brains. Significant difference: ${ }^{*} p$

$6<0.05$ and $*^{*} \mathrm{p}<0.01$, ANOVA with Tukey's post-hoc test. $(\mathrm{C}-\mathrm{G})$ Hippocampal CA1 
1 neurons were cotransfected with pCAG-miR29a/b-1 and pCAG-EGFP by in utero

2 electroporation at E15.5 and analyzed at P15. Immunohistochemistry was performed with 3 anti-5hmC (C), $-\gamma \mathrm{H} 2 \mathrm{AX}(\mathrm{D})$, and -GFP antibodies in Nex-Cre/Pol $\beta^{f l / f l}$ hippocampus. (C,

4 D) Magnified images of the dashed-line boxed areas in the upper image are shown in the 5 the lower images. The dashed lines in the lower images mark the perimeter of the nucleus. 6 Arrowheads indicate EGFP-positive transfected cells. Scale bars, 10 (the upper) and 5 7 (the lower) $\mu \mathrm{m}$. (E) Distribution histogram shows the number of $\gamma \mathrm{H} 2 \mathrm{AX}$ foci in the 8 transfected $(\mathrm{GFP}(+), \mathrm{n}=137$ cells $)$ and the surrounding untransfected $(\mathrm{GFP}(-), \mathrm{n}=522$ 9 cells) nuclei of $N e x-C r e / P o l \beta^{f l f l}$ hippocampus. The Kolmogorov-Smirnov (KS) test 10 shows the significant difference between GFP(-) and GFP(+) cells. (F, G) Histograms 11 show the average number of $\gamma \mathrm{H} 2 \mathrm{AX}$ foci $(\mathrm{F})$ and percentage of focus-positive cells $(\mathrm{G})$ 12 in the GFP(+) and the surrounding GFP(-) nuclei of Nex-Cre/Polpllfl CA1 cells. Data are 13 the mean \pm SEM from three different brains. Significant difference: $* * p<0.01$ and $* * * p$ $14<0.001$, Student's t-test. $(\mathrm{H}-\mathrm{K})$ Cortical upper layer neurons were cotransfected with 15 pCAG-TET1CD and pCAG-EGFP by in utero electroporation at E15.5 and analyzed at 16 P7. Immunohistochemistry was performed with anti-5hmC (H), $-\gamma \mathrm{H} 2 \mathrm{AX}(\mathrm{I})$ and -GFP antibodies in Nex-Cre/Pol $\beta^{f l f l}$ and Polfllfl cortex. Arrowheads indicate EGFP-positive 18 transfected cells. Scale bar, $10 \mu \mathrm{m}$. (J, K) Histograms show the average number of $\gamma \mathrm{H} 2 \mathrm{AX}$ 19 foci $(\mathrm{J})$ or percentage of focus-positive cells (K) in the GFP(+) and surrounding GFP(-) 20 nuclei of $N e x-C r e / P o l f^{f l f l}(\mathrm{n}=160$ cells, $\mathrm{n}=950$ cells $)$ and $P$ Polf ${ }^{f l / f l}(\mathrm{n}=161$ cells and $\mathrm{n}=$ 21966 cells) cortex. Data are the mean \pm SEM from three different brains. Significant difference: ${ }^{*} p<0.05, * * p<0.01$, and ${ }^{* * *} p<0.001$, ANOVA with Tukey's post-hoc test. 


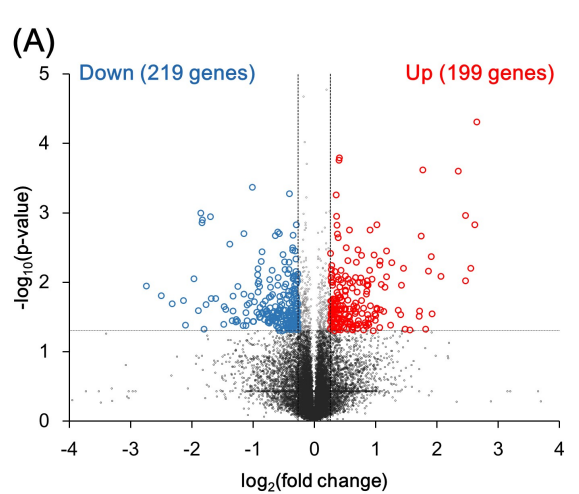

(D) Top 20 canonical pathways

Estrogen-mediated S-phase Entry
Cycle: G1/S Checkpoint Regulation Cyclins and Cell Cycle Regulation Cyclins and Cell Cycle Regulation Molecular Mechanisms of Cancer Chronic Myeloid Leukemia Signaling olate Transformations I Role of BRCA1 in DNA Damage Response Hereditary Breast Cancer Signaling
Ketogenesis Cell Cycle Control of Chromosomal Replication Role of CHK Proteins in Cell Cycle Checkpoint Control Assembly of RNA Polymerase I Complex Opioid Signaling Pathway
Mevalonate Pathway 1 Mevalonate Pathway I Death Receptor Signaling Receptor Signaling Glioblastoma Multiforme Signaling Nucleotide Excision Repair Pathway
(B) development and function

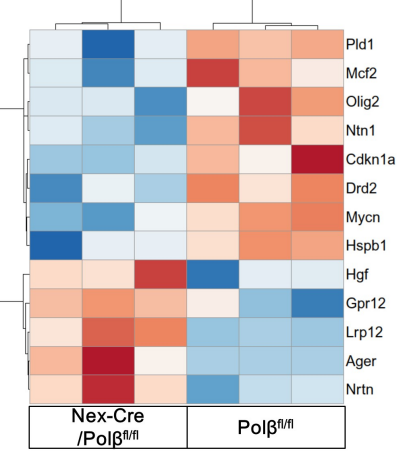

$-\log _{10}(p$-value $)$
(C) Neurological disorders

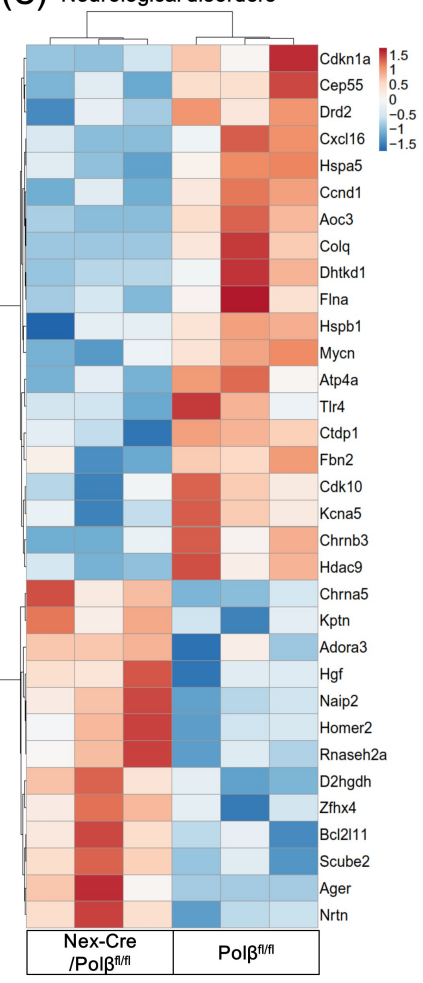

- $\log _{10}(p-v a l u e)$

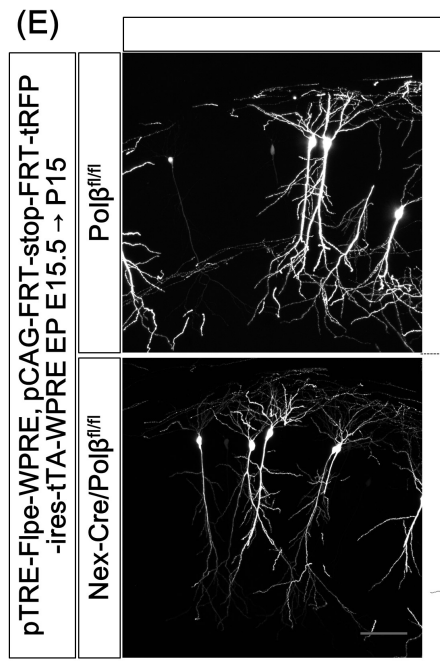
ay $\begin{array}{llll}0.1 & 0.15 & 0.2 & 0.25\end{array}$ .25

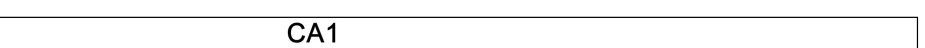

$(\mathrm{F})$
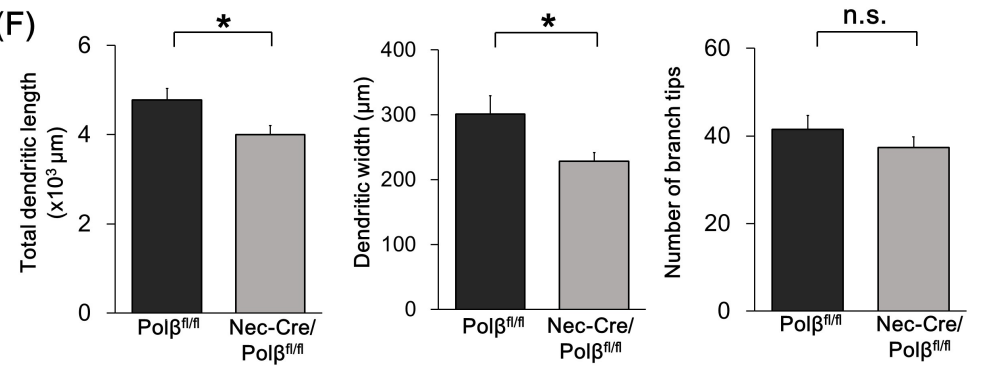

Fig. 5 Pol $\beta$ deficiency affects gene expression and dendrite morphology of 


\section{1 hippocampal neurons during postnatal development.}

2 (A) Volcano plot of RNA-seq data from Pol $\beta^{f l f l}$ and Nex-Cre/Pol $\beta^{f l f l} \mathrm{P} 15$ hippocampus (n $3=3$ ). Differentially expressed genes (DEGs, Nex-Cre/Pol $\beta^{f l f l}$ vs $P o l \beta^{f l f l}, \mathrm{p}<0.05$, fold

4 change $>1.2$ ) are highlighted in blue (down) or red (up). (B, C) Hierarchical clustering 5 with mean-centered $\log _{2}$-FPKM of DEGs related to nervous system development and 6 function (B) or neurological disorders (C). Rows and columns represent genes and 7 samples, respectively. (D) Top 20 canonical pathways predicted by Ingenuity Pathway 8 Analysis. (E) Hippocampal CA1 neurons were cotransfected with FLPe-based Supernova 9 vectors by in utero electroporation at E15.5 and analyzed at P15. Immunohistochemistry 10 was performed with anti-tRFP antibody in Nex-Cre/Pol/flffl and Polffl/fl hippocampus. 11 Examples of z-projected dendritic morphology of CA1 neurons traced with tRFP labeling 12 are shown. Scale bar, $100 \mu \mathrm{m}$. (F) Quantitative analysis for total dendritic length, 13 dendritic width, and number of branch tips. Data are mean \pm SEM from Polpllfl $(\mathrm{n}=18$ 14 cells of 5 animals $)$ and $N e x-C r e / P o l f f l f l l(n=20$ cells of 4 animals $)$ mice. Significant 15 difference: ${ }^{*} \mathrm{p}<0.05$, ANOVA.

16 
(A) $\bigcirc \mathrm{Pol} \beta^{\text {fi/ }}$

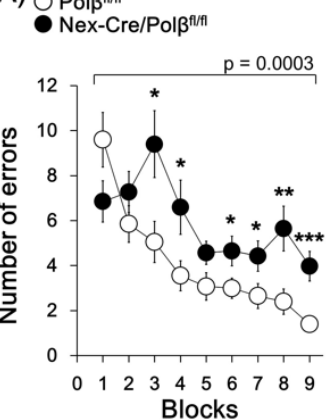

O Polp $\beta^{\text {fl/ }}$

(E)
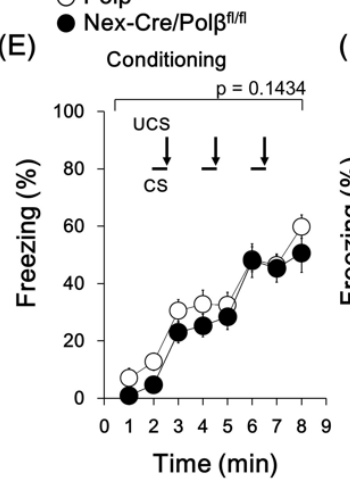

(B)

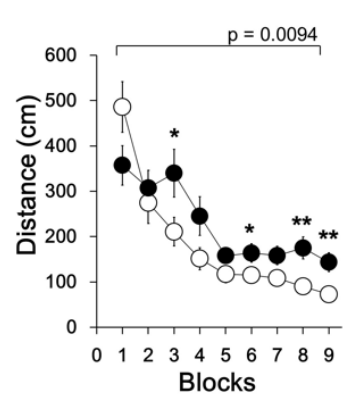

(F)

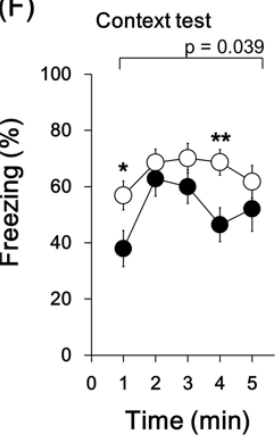

(C)

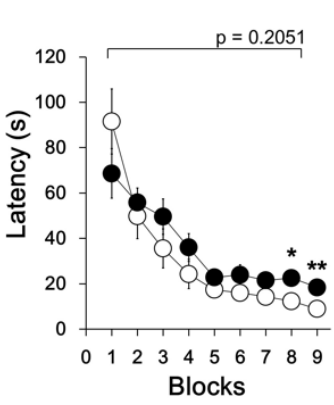

(D)

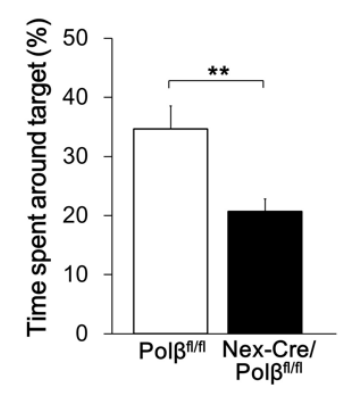

(J)

(G)

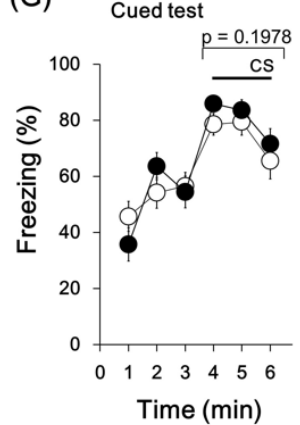

(H)

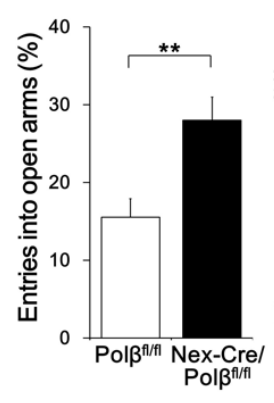

(I)

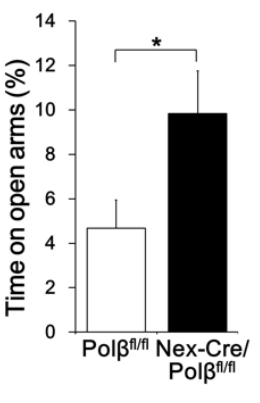

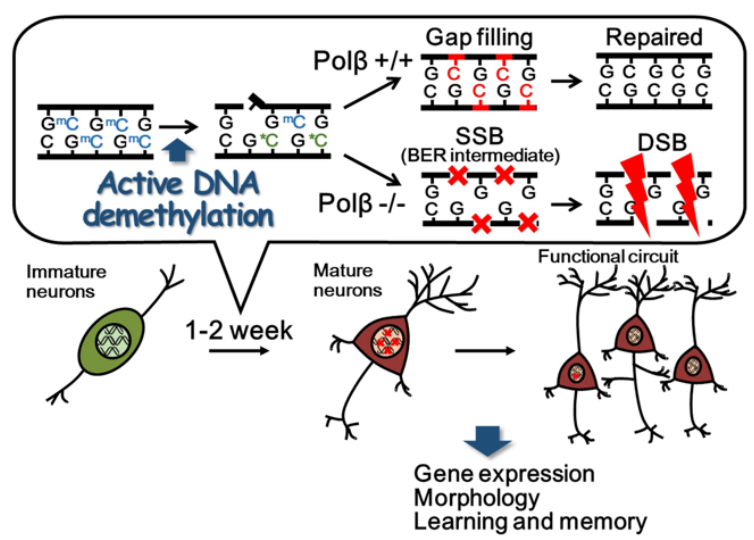

1 Fig. 6 Nex-Cre/Pol $f^{f l f l}$ mice show impaired spatial reference memory and contextual

\section{2 fear memory.}

3 (A-D) The Barnes maze test was performed for Nex-Cre/Polf $\beta^{f l f l}(\mathrm{n}=20)$ and $\operatorname{Pol}^{f l / f l}(\mathrm{n}$

$4=20)$ mice. Quantitative analysis of the number of errors (A), distance traveled (B), and

5 latency $(C)$ before reaching the target hole. Data are mean \pm SEM. Significant differences:

6 p-values of repeated measures ANOVA are indicated. ${ }^{*} \mathrm{p}<0.05, * * \mathrm{p}<0.01$, and $* * * \mathrm{p}<$

7 0.001, ANOVA for 2 blocks of trials. (D) Histogram shows percentage of time spent

8 around the target in the probe test at one day after the acquisition test. Data is mean \pm

9 SEM. Significant differences: **p $<0.01$, ANOVA. (E-G) Quantitative analysis of 
1 freezing behavior (\%) in the conditioning session (E), contextual (F) and cued (G) test in

2 the fear conditioning test. Data is mean $\pm \mathrm{SEM}$ from Nex-Cre/Pol$/ \beta^{f l f l}(\mathrm{n}=20)$ and $P o l \beta^{f l f l}$

$3(\mathrm{n}=20)$ mice. Significant differences: $\mathrm{p}$-values of repeated measures ANOVA are

4 indicated. ${ }^{*} \mathrm{p}<0.05,{ }^{*} \mathrm{p}<0.01$, ANOVA for each duration. (H, I) Histograms show

5 quantitative analysis of entries into open arms (H) and time spent in open arms (I) in the

6 elevated plus maze test. Data are mean \pm SEM from Nex-Cre/Pol $\beta^{f l f l}(\mathrm{n}=20)$ and $P o l \beta^{f l f l}$

$7 \quad(\mathrm{n}=20)$ mice. Significant difference, ${ }^{*} \mathrm{p}<0.05,{ }^{*} \mathrm{p}<0.01$, ANOVA. (J) Proposed model

8 of Polß-dependent active DNA demethylation during postnatal neuronal development. 


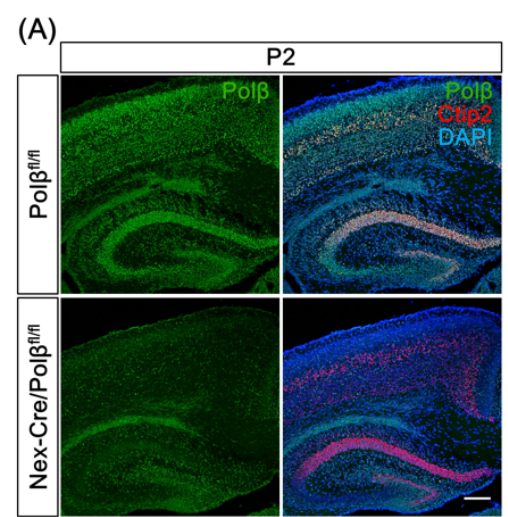

(B)

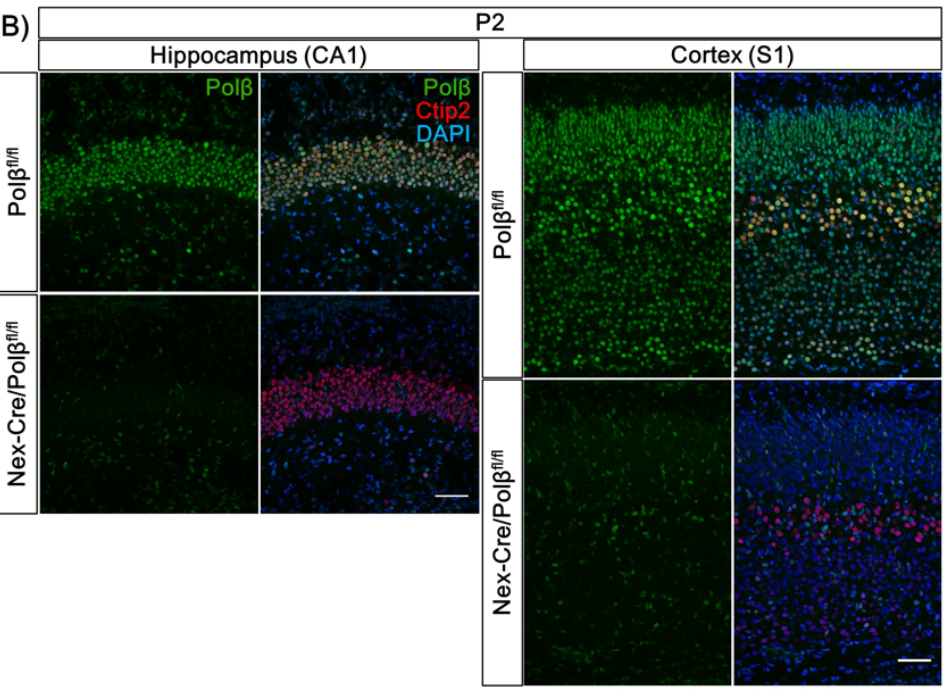

(C)
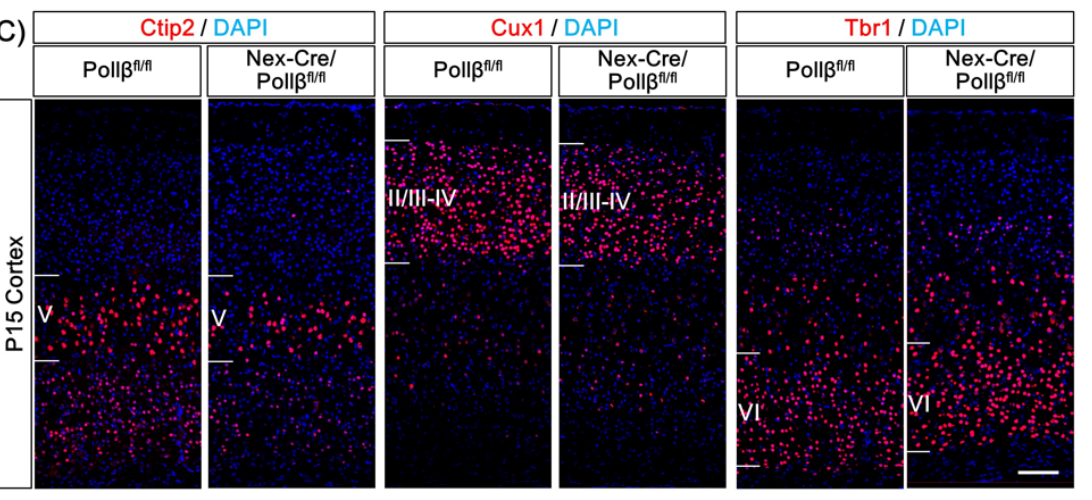

(D)

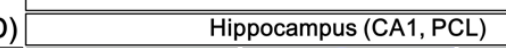

P15
(E)
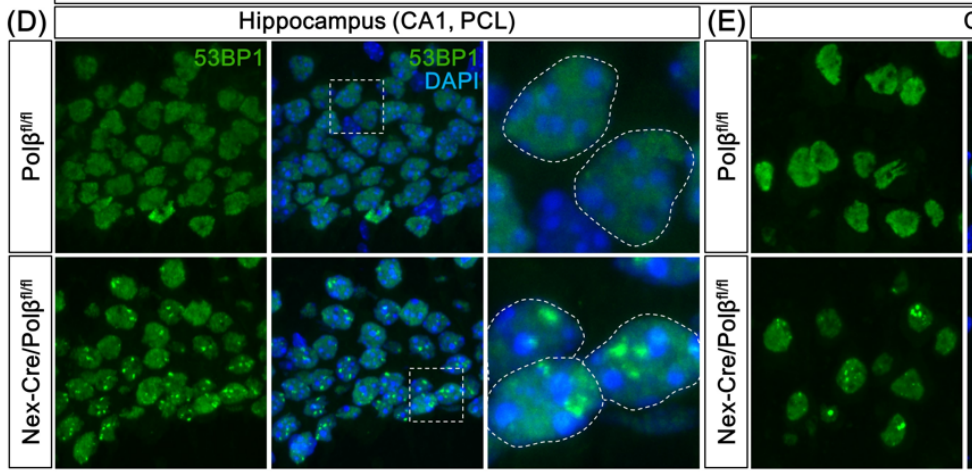

Cortex (S1, Layer V)

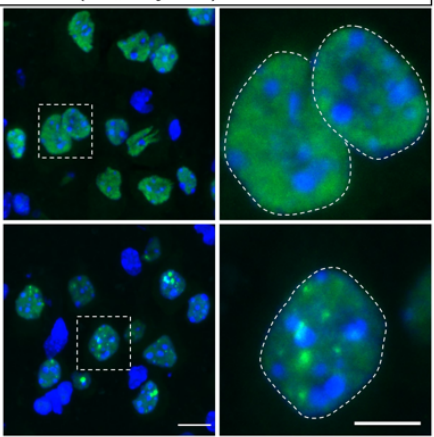

1 Supplemental Fig. 1 Nex-Cre/Polp ${ }^{f l / f l}$ mice exhibit DSB formation in postnatal

\section{2 hippocampus and cortex.}

3 (A) Immunohistochemistry was performed with anti-Pol $\beta$ and -Ctip2 antibodies in P2

4 Nex-Cre/Pol $\beta^{f l / l}$ and control Polp $\beta^{f / f l}$ cortex and hippocampus. Scale bar, $400 \mu \mathrm{m}$. (B)

5 Magnified images are hippocampal CA1 area and somatosensory area 1 (S1) in the cortex.

6 Scale bar, $100 \mu \mathrm{m}$. (C) Immunohistochemistry was performed with anti-Ctip2, -Cux1,

7 and -Tbr1 antibodies in P15 Nex-Cre/Pol $f^{t l f l}$ and Pol $f^{f l f l}$ cortex. Scale bar, $200 \mu \mathrm{m}$. (D) 
1 Immunohistochemistry was performed with anti-53BP1 antibody in P15 Nex-Cre/Polffllfl

2 and Pol $\beta^{f l f l}$ cortex and hippocampus. Magnified images of the boxed areas are shown in

3 the right panels. The dashed lines in the rightmost images mark the perimeter of the

4 nucleus. Scale bars, 10 (the center) and 5 (the right) $\mu \mathrm{m}$.

5 


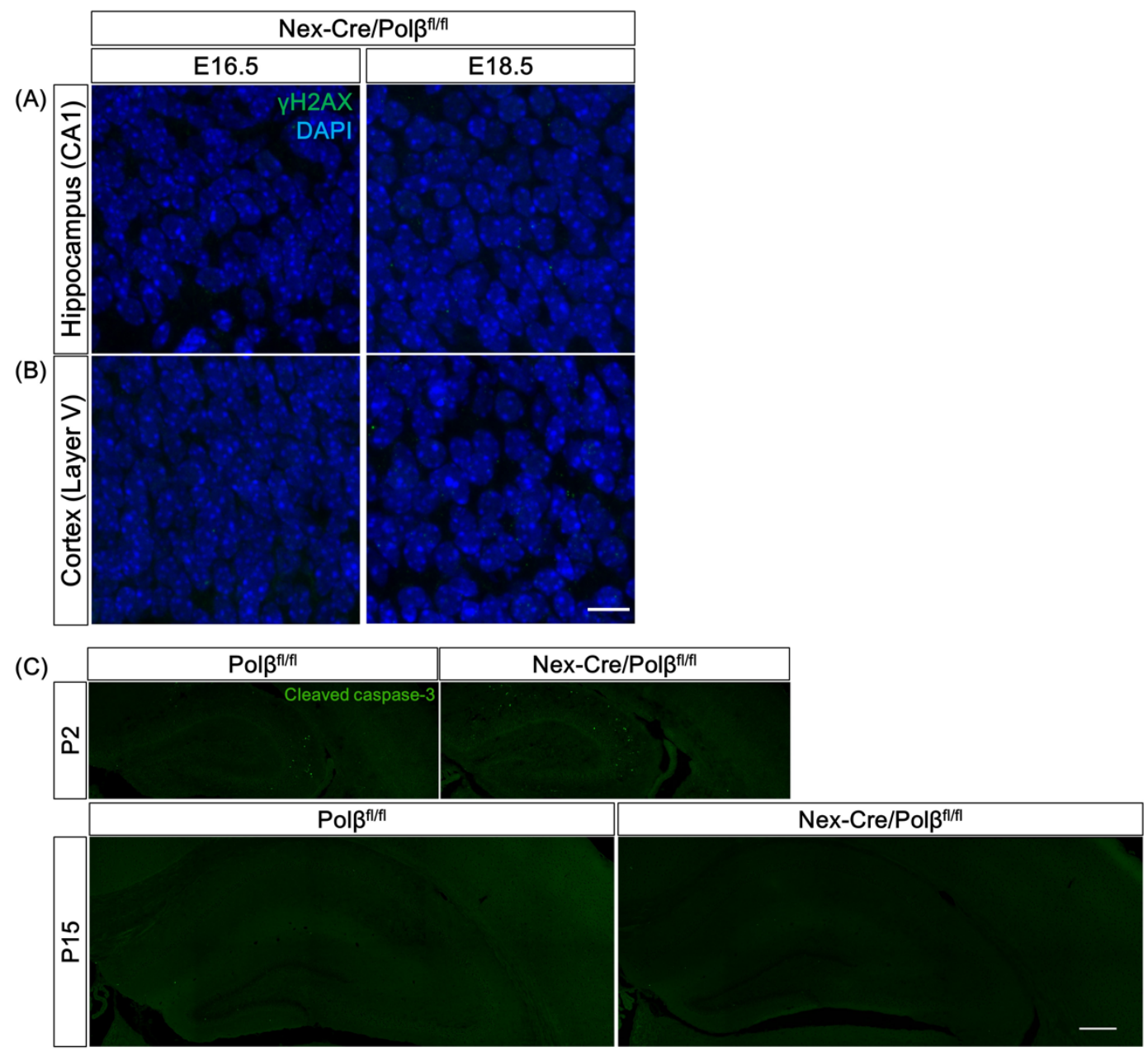

1 Supplemental Fig. 2 Nex-Cre/Pol $\beta^{f l f l}$ mice exhibit the extent of apoptotic cells similar

2 to that control hippocampus and cortex.

3 (A, B) Immunohistochemistry was performed with anti- $\gamma \mathrm{H} 2 \mathrm{AX}$ antibody in Nex$4 \quad$ Cre/Pol $\beta^{f l f l}$ and Pol $\beta^{f l f l}$ hippocampus (A) and cortex (B) at E16.5 and E18.5. Scale bar, $510 \mu \mathrm{m}$. (C) Immunohistochemistry was performed with anti-cleaved caspase 3 antibody 6 in Nex-Cre/Pol $\beta^{f l / f l}$ and Pol $\beta^{f l f l}$ hippocampus and cortex at P2 and P15. Scale bar, $400 \mu \mathrm{m}$. 

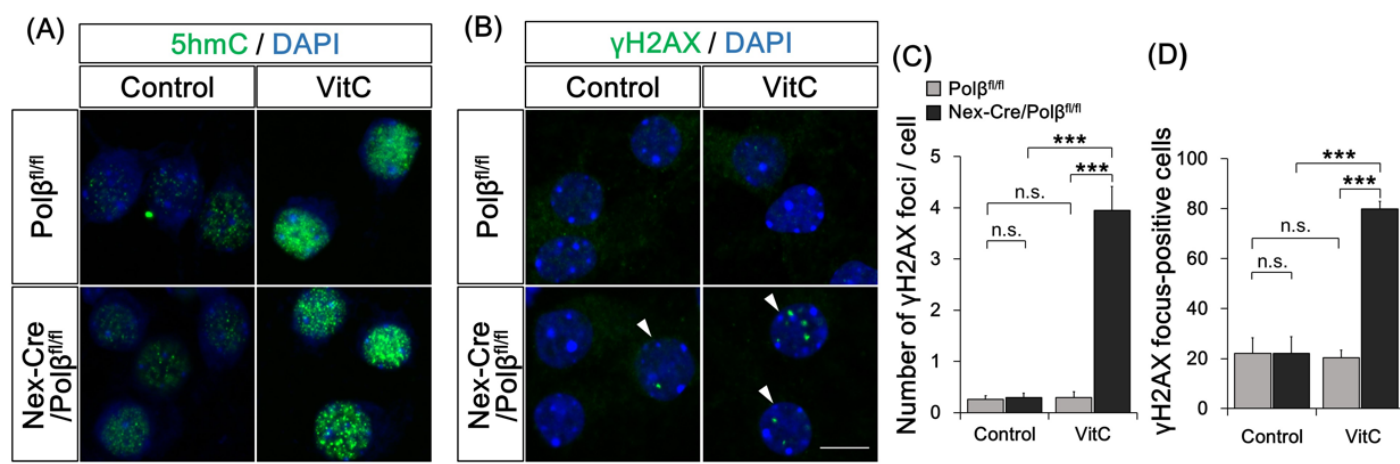

1 Supplemental Fig. 3 Loss of Pol in active DNA demethylation causes DSBs in 2 neurons.

3 (A, B) Primary cultured neurons from E16.5 Nex-Cre/Pol $\beta^{f l f l}$ or Polfflfl cortex were

4 treated with vitamin $\mathrm{C}$ (VitC) for $24 \mathrm{~h}$ at $14 \mathrm{DIV}$ and immunocytochemistry was

5 performed with anti-5hmC (A) or anti- $\gamma \mathrm{H} 2 \mathrm{AX}(\mathrm{B})$ antibodies. Arrowheads indicate

$6 \gamma \mathrm{H} 2 \mathrm{AX}$ focus-positive cells. (C, D) Histograms show the mean number of $\gamma \mathrm{H} 2 \mathrm{AX}$ foci

7 in each nucleus (C) and the percentage of $\gamma \mathrm{H} 2 \mathrm{AX}$ focus-positive cells. Data are the mean

$8 \pm$ SEM from control or VitC-treated Nex-Cre/Pol $\beta^{f l f l}(\mathrm{n}=48$ cells, $\mathrm{n}=62$ cells $)$ and

$9 \quad \operatorname{Pol}^{f l f l}(\mathrm{n}=54$ cells, $\mathrm{n}=49$ cells $)$ cortical neurons in three independent experiments.

10 Significant difference: $* * * p<0.001$, ANOVA with Tukey's post-hoc test. 
(A)

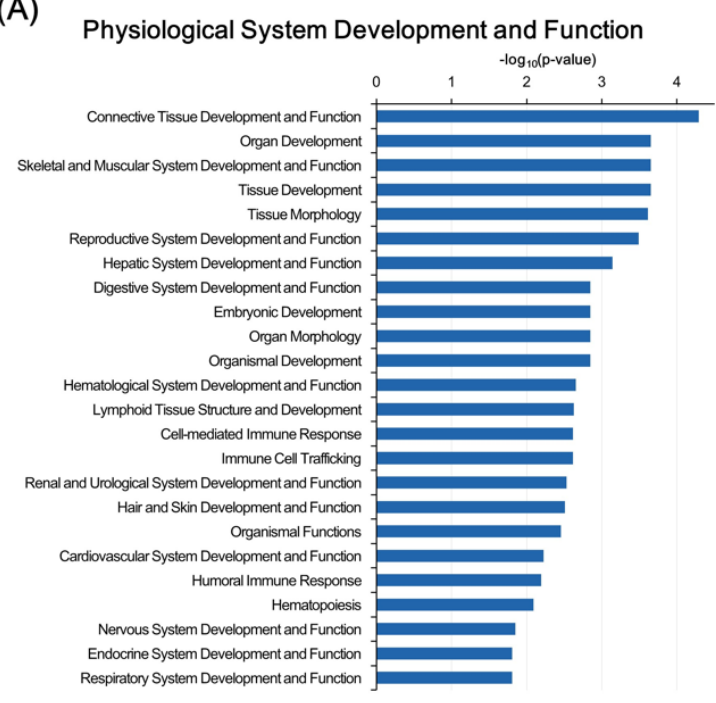

(C) Disease and Disorders

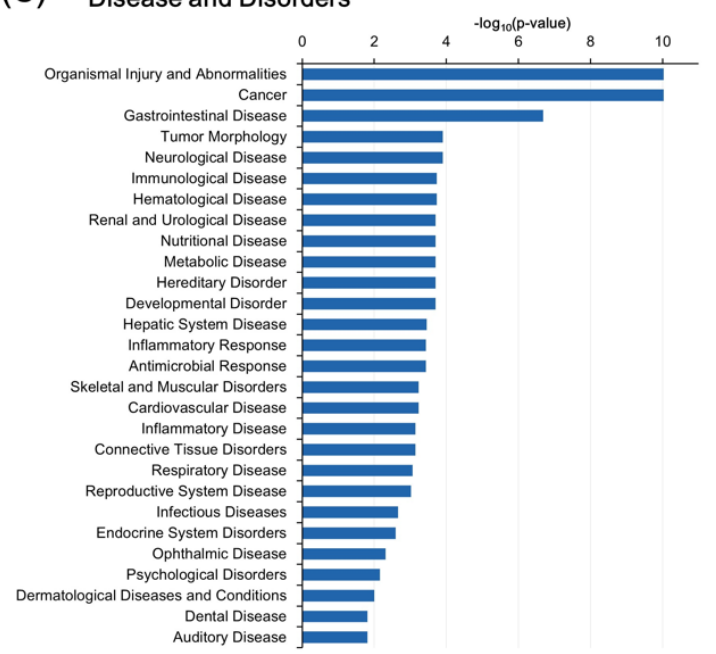

(B)

Molecular and Cellular Functions

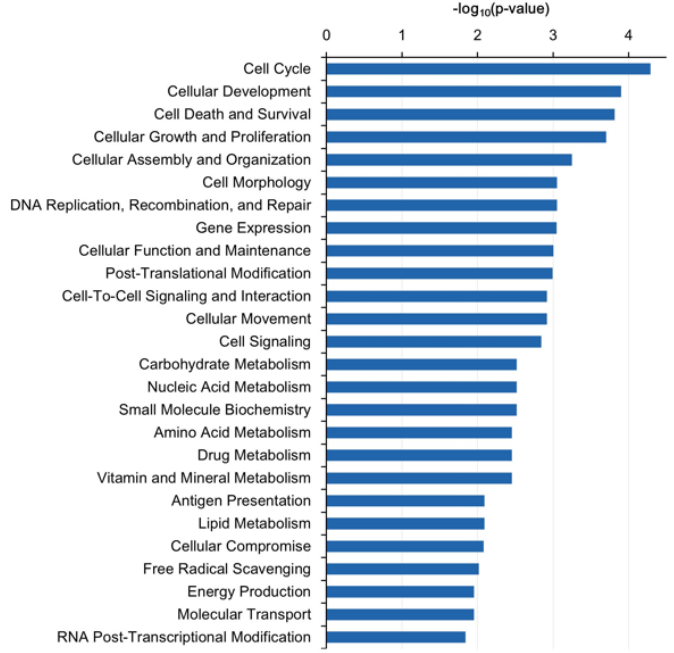

(D)

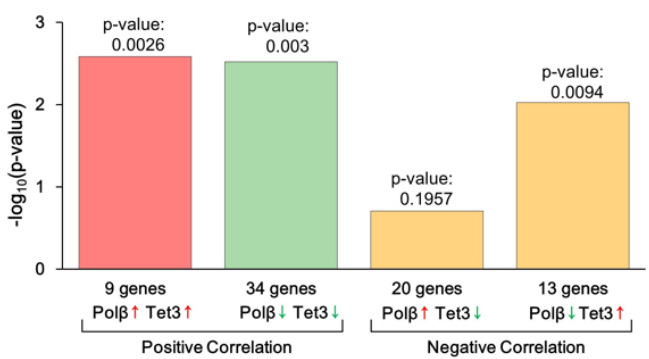

\section{Supplemental Fig. 4 Pol $\beta$ deficiency affects gene expression and dendrite}

2 morphology of hippocampus neurons during postnatal development.

3 (A-C) Functional annotation of DEGs between Nex-Cre/Pol $\beta^{f l / f l}$ and Pol $\beta^{f l f l}$ hippocampus

4 in the three primary categories by IPA $(p<0.05$, Fisher's exact test $)$ : Physiological System

5 Development and Function (A), Molecular and Cellular Functions (B), and Disease and

6 Disorders (C). (D) Comparative analysis of DEGs between Pol $\beta$-deficient hippocampus

7 and TET3 shRNA-transfected hippocampal neuronal culture. 
bioRxiv preprint doi: https://doi.org/10.1101/852053; this version posted November 24, 2019. The copyright holder for this preprint (which was not certified by peer review) is the author/funder. All rights reserved. No reuse allowed without permission.

1 Supplemental Table 1. Summary of comprehensive behavioral test battery

\begin{tabular}{|c|c|c|}
\hline Test & Measure & p-value \\
\hline \multicolumn{3}{|l|}{ General Health } \\
\hline Body weight & Weight (g) & 0.3496 \\
\hline Body temperature & Temperature $\left({ }^{\circ} \mathrm{C}\right)$ & 0.5477 \\
\hline Grip strength & Strength $(\mathrm{N})$ & 0.8528 \\
\hline Wire hang & Latency to fall (sec) & 0.4578 \\
\hline \multirow[t]{3}{*}{ Light/dark transition test } & Stay time in light (sec) & 0.8748 \\
\hline & Number of transitions & 0.8044 \\
\hline & Latency to light (sec) & 0.4936 \\
\hline \multirow[t]{4}{*}{ Open field test } & Total distance $(\mathrm{cm})$ & G: $0.9697, G \times T:<0.0001^{* * *}$ \\
\hline & Vertical activity & G: $0.4896, \mathrm{G} \times \mathrm{T}: 0.898$ \\
\hline & Center time (sec) & G: $0.8841, G \times \mathrm{T}: 0.9607$ \\
\hline & Stereotypic counts & G: $0.4577, G \times T: 0.0032^{* *}$ \\
\hline \multirow[t]{2}{*}{ Elevated plus maze test } & Entries into open arms (\%) & $0.0023^{* *}$ \\
\hline & Time on open arms (\%) & $0.0303^{*}$ \\
\hline Rotarod & Latency to fall (sec) & G: $0.0703, G \times$ Tr: 0.825 \\
\hline Hot plate & Latency (sec) & 0.6464 \\
\hline \multicolumn{3}{|l|}{ Social Interaction (Novel environment) } \\
\hline & Total duration of contact (sec) & $0.0445^{*}$ \\
\hline & Number of contacts & 0.1277 \\
\hline & Mean duration / contact (sec) & 0.5133 \\
\hline \multicolumn{3}{|l|}{3 chamber social approach test } \\
\hline Sociability & Time spent around stranger cage (\%) & 0.7741 \\
\hline Preference & Time spent around stranger cage (\%) & 0.0748 \\
\hline \multicolumn{3}{|l|}{ Prepulse inhibition test } \\
\hline Startle response & Startle amplitude to $110,120 \mathrm{~dB}$ & G: $0.0062, G \times S: 0.0421^{*}$ \\
\hline \multirow[t]{2}{*}{ Prepulse inhibition } & $\mathrm{PPI}(\mathrm{PPI} 74,78 \mathrm{~dB}$ - startle $110 \mathrm{~dB})(\%)$ & G: $0.1219, G \times P: 0.8899$ \\
\hline & PPI (PPI 74, $78 \mathrm{~dB}$ - startle $120 \mathrm{~dB})(\%)$ & G: $0.0333^{*}, G \times P: 0.1127$ \\
\hline \multirow[t]{2}{*}{ Porsolt forced swim } & Immobility (\%) Day1 & G: $0.1147, G \times T: 0.2675$ \\
\hline & Immobility (\%) Day2 & G: $0.1134, \mathrm{G} \times \mathrm{T}: 0.0284^{*}$ \\
\hline T-maze test & Correct response (\%) & G: $0.0256^{*}, \mathrm{G} \times \operatorname{Tr}: 0.3757$ \\
\hline (spontaneous alteration) & Latency (sec) & G: $0.1612, G \times$ Tr: 0.2337 \\
\hline \multicolumn{3}{|l|}{ Barnes maze test } \\
\hline \multirow[t]{4}{*}{ Acquisition } & Number of errors & G: $0.0003^{* * *}, G \times \operatorname{Tr}: 0.0031^{* *}$ \\
\hline & Distance traveled & G: $0.0094^{* *}, \mathrm{G} \times \operatorname{Tr}: 0.0058^{* *}$ \\
\hline & Latency & G: $0.2051, G \times$ Tr: 0.1263 \\
\hline & Omission errors & G: $0.375, G \times \operatorname{Tr}: 0.5279$ \\
\hline Probe test (1 day) & Time spent around target hole (\%) & $0.0031^{* *}$ \\
\hline Probe test (1 month) & Time spent around target hole (\%) & $0.0254^{*}$ \\
\hline \multicolumn{3}{|l|}{ Fear conditioning } \\
\hline \multirow[t]{2}{*}{ Conditioning } & Freezing (\%) & G: $0.1434, G \times T: 0.883$ \\
\hline & Distance traveled & G: $0.0181^{*}, \mathrm{G} \times \mathrm{T}: 0.5153$ \\
\hline \multirow[t]{2}{*}{ Context testing ( 1 day) } & Freezing (\%) & G: $0.0809, G \times T 0.8485$ \\
\hline & Distance traveled & G: $0.0195^{*}, \mathrm{G} \times \mathrm{T}: 0.8551$ \\
\hline \multirow{2}{*}{$\begin{array}{l}\text { Cued testing with altered context (1 } \\
\text { day) }\end{array}$} & Freezing during CS (\%) & G: $0.4288, G \times T: 0.8812$ \\
\hline & Distance traveled during CS & G: $0.4428, G \times \mathrm{T}: 0.9637$ \\
\hline \multirow[t]{2}{*}{ Context testing (1 month) } & Freezing (\%) & G: $0.039^{*}, \mathrm{G} \times \mathrm{T}: 0.2822$ \\
\hline & Total distance traveled & G: $0.0182^{*}, \mathrm{G} \times \mathrm{T}: 0.1719$ \\
\hline \multirow{2}{*}{$\begin{array}{l}\text { Cued testing with altered context (1 } \\
\text { month) }\end{array}$} & Freezing during CS (\%) & G: $0.1978, G \times$ T: 0.9227 \\
\hline & Distance traveled during CS & G: $0.2095, G \times T: 0.7771$ \\
\hline Tail suspension test & Immobility (\%) & G: $0.9557, \mathrm{G} \times \mathrm{T}: 0.1154$ \\
\hline \multirow{2}{*}{ Home cage social interaction } & Mean number of particles & G: 0.9939 (light: 0.925, dark: 0.8939) \\
\hline & Activity level & G: 0.0516 (light: 0.2802 , dark: $0.0215^{*}$ ) \\
\hline
\end{tabular}

${ }^{*} p<0.05,{ }^{* *} p<0.01$, and ${ }^{* * *} p<0.001(n=20$ in each group, one-way or two-way repeated measures ANOVA). In two-way repeated measures ANOVA, p-values of interaction of genotype $(G)$ with time $(T)$, trial $(T r)$, startle $(S)$, or PPI $(P)$ are shown. 